\title{
Ameliorative Effects of Panax Ginseng on Lung of Lambada Cyhalotherin-intoxicated Rats
}

\section{Original Article}

\author{
Karim Zaied, Hanaa M. Mohamed, Sanaa M. Abd El-Twab and \\ Manal Abdul-Hamid
}

Department of Zoology, Faculty of Science, Beni-Suef University, Egypt

\begin{abstract}
Introduction: Lambada-cyhalotherin (LCT) caused severe oxidative damage in liver, lung and testis.

Aim of the Study: The objective of this research was to evaluate the ameliorative activity and underlying techniques of pure Panax ginseng $(\mathrm{G})$ using rat model of LCT-induced lung damage.

Materials and Methods: 36 male adult laboratory rats Rattus norvegicus domestica in weights around $135 \pm 10 \mathrm{~g}$ were separated into 6 experimental groups: $1^{\text {st }}$ control group. $2^{\text {nd }}$ and $3^{\text {th }}$ groups were G groups (100 and $200 \mathrm{mg} \mathrm{G} / \mathrm{kg} \mathrm{b.} \mathrm{wt.)} \mathrm{LCT}$ group was given by oral gavage LCT $(61.2 \mathrm{mg} / \mathrm{kg} \mathrm{b}$. wt. $)$ that is equivalent to $1 / 10 \mathrm{of}$ LD50. The $5^{\text {th }}$ and $6^{\text {th }}$ groups were cotreated with two doses of $\mathrm{G}$.

Results: LCT significantly decreased superoxide dismutase (SOD), catalase (CAT) and total thiol (T. thiol) and increased lipid peroxidation (LPO). mRNA and protein expression levels of p53 gene (apoptotic gene) were increased, whereas, Bcl-2 gene (anti-apoptotic gene) mRNA and protein expression levels were decreased in LCT-treated animals. Also, light microscopic and ultrastructure studies for lung tissues of LCT-treated animals showed marked hyperplasia of dilated bronchioles wall, RBCs extravasation in bronchiolium lumen and mononuclear leukocytic infiltration in parenchyma. Additionally, blood vessels congested with thickened walls, alveoli appeared collapsed with compensatory expansion of adjacent alveoli divided by thickened inter-alveolar septa, besides to damage in type 1 and type 2 pneumocytes. G co-treatment attenuated oxidative stress biomarkers. Both tested doses of G significantly decreased p53 and elevate Bcl-2 mRNA and protein expression levels and revealed significant amelioration and restoration of normal histology and ultrastructure of lung.

Conclusion: In summary, G has exhibited ameliorative activity against oxidative stress induced by LCT in lung, apoptosis, histopathological and ultrastructural changes in albino rats.
\end{abstract}

Received: 18 May 2020, Accepted: 29 May 2020

Key Words: Antioxidants enzyme activities; histopathology and ultrastructure of the lung; lambda-cyhalothrin; panax ginseng.

Corresponding Author: Manal Abdul-Hamid, PhD, Department of Zoology, Faculty of Science, Beni-Suef University, Egypt, Tel.: +20 1005168380, E-mail: medo_bio@yahoo.com

ISSN: 1110-0559, Vol. 44, No.1

\section{INTRODUCTION}

Pesticides are directly applied to the environment, agricultural land, vegetation, animal housing areas and animals ${ }^{[1]}$. Controlling flies, mosquitoes, ticks and cockroaches, which can act as disease vectors for both human and animals, is the most important application of $i^{[2]}$. Pyrethroids are artificial analogs for natural pyrethrum but more toxic and longer lasting ${ }^{[3,4]}$. Because of their high effectiveness, low toxicity to birds and mammals and fast biodegradability, they are chosen over organophosphorus, organochlorine and carbamate pesticides ${ }^{[5]}$. Despite claiming that they have a low mammalian toxicity, several investigations reported the toxicological evidence of pyrethroid among various species of animals; in rats ${ }^{[6]}$, in mice $^{[7]}$, in fishes ${ }^{[8]}$ and in rabbit ${ }^{[9]}$.

Lambda cyhalothrin (LCT), type II pyrethroid pesticide, used in public and animal health applications ${ }^{[10,11]}$. Residues of LCT was observed in dairy cows' blood and milk ${ }^{[13]}$, vegetables, fruits ${ }^{[12]}$ and in meat of cattle ${ }^{[14]}$. Placental transference of LCT in goats was observed ${ }^{[15]}$. LCT has been found to accumulate in biological membranes of tissue initiating reactive oxygen species (ROS) which alter the antioxidant systems and increase lipids peroxidation (LPO) in mammals ${ }^{[16]}$. LCT metabolism occur rapidly in liver by hydrolytic cleavage of ester and oxidative pathways via CYP450 enzymes leading to ROS ${ }^{[17]}$. Large quantities of ROS able to oxidize lipids, proteins and nucleic acids, thus lead to the formation of a wide spectrum of diseases as diabetes, obesity, neurodegenerative diseases, atherosclerosis, cardiovascular disease, and cancer ${ }^{[18]}$ and associated with accelerated levels of inflammation ${ }^{[19]}$.

Lung damage is one of pesticides' side effects on mammals ${ }^{[20]}$. Intraperitoneal injection of LCT to albino rats showed some clinical symptoms include nasal discharge, severe coughing, anorexia, fatigue, emaciation and depression ${ }^{[21]}$. In addition some macroscopic (lung consolidation and congestion) and microscopic (bronchiolitis, abscessation, pulmonary oedema and hemorrhage findings were previously reported ${ }^{[9,21,22]}$. Arafa et $a .^{[23]}$ reported that ultrastructurally, lung of $\alpha$-cypermethrin- treated rats exhibited thickening of 
inter-alveolar septa with multiple cellular infiltration. Pneumocytes type II showed multiple vacuoles in the cytoplasm. The interstitium exhibited severe hemorrhage. Alveolar spaces appeared narrow.

Panax ginseng $(\mathrm{G})$ is a worldwide famous medicinal herb. It is utilized for treatment of various diseases like gastrointestinal diseases, respiratory diseases and as a general tonic ${ }^{[24]}$. Ginsenosides is the most important active ingredient in $\mathrm{G}$. It protected isolated cells from oxidative damage ${ }^{[25]}$, suppress $\mathrm{LPO}^{[26]}$, regulate lipids metabolism, Foster anti-oxidation activity and improve immune activity ${ }^{[27]}$. Small limited clinical trials have shown potential therapeutic efficacy of $\mathrm{G}$ extract in chronic obstructive pulmonary disease COPD patients ${ }^{[28,29]}$. Korean Red Ginseng (KRG) extract has was observed to prevent acute respiratory disease in a clinical trial ${ }^{[30]}$. In preliminary study of Lee et al. ${ }^{[31]}$, KRG hot water extract had significant inhibitory activity against an acute lung injury model for the mouse. Mohi El-Din et al. ${ }^{[21]}$ found that $\mathrm{G}$ showed a reduction in lung sensitivity against LCT toxicity; showing moderate hyperplasia in bronchioles wall with inflammatory cell clearance and mild interstitial alveolitis with little neutrophils number observed in the rats compared with LCT- treated rats.

With this background, G was found to have the most hopeful proof for regulating the immune response, especially cell-mediated immunity and ability of clinical application for chronic pulmonary diseases. Thus our research was conducted to determine the possible therapeutic potential of G toward pulmonary damage caused by LCT via oxidative stress, apoptosis, histopathological and ultrastructural changes in lung of adult albino rats.

\section{MATERIALS AND METHODS}

\section{Chemicals}

Lambda-cyhalothrin (LCT), with commercial name Lambada C 5\%, was purchased from Pharmacure for Chemicals and Pharmaceuticals, Egypt. Pure ginseng was purchased from PHARCO Pharmaceutical Industries (Cairo, Egypt). All chemical with analytical quality and were obtained from standard commercial products.

\section{Animals and experimental design}

The present study used male adult laboratory rats (Rattus norvegicus domestica), which weighed around $135 \pm 10 \mathrm{~g}$. They were collected from the National Research Center (NRC), Doki, Giza, Egypt and kept under observation to exclude any intercurrent infection for 14 days before the start of the experiment. The animals selected were kept in plastic cages with good aeration at temperature $\left(25 \pm 5{ }^{\circ} \mathrm{C}\right)$, normal dark / light cycle of 12 hours and humidity $(55 \pm 5 \%)$. According to the 1993 Canadian Council for Animal Care (CCAC) principles and guidelines, the rats were supplied with known composition basal diet and water ad libitum throughout study time.

Six groups of Rats (6 per group) were separated randomly (6 per group) as follows:
Group 1 (C, control): rats received normal saline through intraperitoneal (i.p.) injection daily for 60 days.

Group 2 (G 100): rats received $G$ at a daily dose of $100 \mathrm{mg} / \mathrm{kg}$ b. wt dissolved in normal saline ${ }^{[32]}$ by i.p. injection for 60 days.

Group 3 (G 200): rats received $G$ at a daily dose of $200 \mathrm{mg} / \mathrm{kg}$ b. $\mathrm{wt}^{[21]}$ by i.p. injection for 60 days.

Group 4 (LCT): rats received LCT at a daily dose of $61.2 \mathrm{mg} / \mathrm{kg} \mathrm{b}$. wt $(10 \% \text { of LD50 })^{[33]}$ by oral gavage for 60 days.

Group 5 (LCT+G100): rats received the same dose of LCT, as in group 4, followed immediately by G, as in group 2, daily for 60 days.

Group $6(\mathbf{L C T}+\mathbf{G 2 0 0})$ : rats received the same dose of LCT, as in group 4, followed immediately by G, as in group 3, daily for 60 days.

The doses were adjusted weekly regarding to body weight changes to sustain comparable dose per kg rat's body weight till the end of experiment period.

\section{Samples preparation}

Body weight change was determined from the gap between the initial weight at the beginning and the final weight upon completion of study. Before weights recoding all rats were fasted for ten hours (water ad libitum) to exclude feeding error. All groups of rats are sacrificed under anesthesia of diethyl ether at the end of the two months. Two lungs were rapidly taken out, washed with ice-cold saline and splitted into 3 parts. $1^{\text {st }}$ lung part $(10 \% \mathrm{w} / \mathrm{v})$ was homogenized using Teflon tissue homogenizer (Omni International Inc., Kennesaw, GA, USA) in phosphate-buffered saline (PBS), Then for $10 \mathrm{~min}$ using centrifuge at $3000 \mathrm{rpm}$ the clear homogenates were obtained and frozen at $-80^{\circ} \mathrm{C}$ for subsequent analysis of oxidative stress parameters, the $2^{\text {nd }}$ part was kept frozen at $-80^{\circ} \mathrm{C}$ for gene and protein expression analysis. The $3^{\text {rd }}$ part was used for electron and light microscopic examination.

\section{Biochemical assays}

\section{Assay of oxidative stress and antioxidant defense system}

For lung homogenates, LPO content was calculated by measuring malondialdehyde (MDA) content using the Preuss et $a l .{ }^{[34]}$ method. Total thiol (T. thiol) content and the antioxidant enzymes activities; catalase (CAT) and superoxide dismutase (SOD) were estimated using the methods of Koster et al. ${ }^{[35]}$, Cohen et al. ${ }^{[37]}$ and Marklund and Marklund ${ }^{[36]}$, respectively.

\section{$R N A$ isolation and quantitative reverse transcription polymerase chain reaction ( $q R T-P C R)$}

LCT effect on on mRNA abundance of $\mathrm{p} 53$ and Bcl-2 by qRT-PCR according to Mahmoud et al. ${ }^{[38]}$. Complementary 
DNAs were synthesized from $2 \mu \mathrm{g}$ RNA and were amplified using SYBR Green master mix (Thermo Fisher Scientific, USA) with the primer sets listed in (Table 1). qPCR was conducted and the amplification data was analyzed by the $2-\Delta \Delta \mathrm{Ct}$ method ${ }^{[39]}$. The results were normalized to $\beta$-actin and shown as percentage of control.

Table 1: Primer pairs used for qPCR

\begin{tabular}{llc}
\hline & & \multicolumn{1}{c}{ Primer sequence } \\
\hline P53 & $\begin{array}{l}\text { Forward primer :5'-GAGCTGAATGAGGCCTTGGA -3' } \\
\text { Reverse primer:5'- CTGAGTCAGGCC CTTCTGTCT T -3' }\end{array}$ & NM_022112 \\
Bcl-2 & Forward primer : 5'-CCT GTG GAT GAC TGA GTA CC-3' \\
& Reverse primer 5'-GAG ACA GCC AGG AGA AAT CA-3' \\
Beta actin & Forward primer :5'- -GGTCGGTGTGAACGGATTTGG -3 \\
& Reverse primer:5'-ATGTAGGCCATGAGGTCCACC-3 & XM_017593963.1 \\
\hline
\end{tabular}

\section{Western blot analysis}

LCT effect on p53 and Bcl-2 expression levels were evaluated from the frozen lung samples by chemiluminescence kit (BIORAD, USA $)^{[40]}$. $\beta$-actin was used as a loading control.

\section{Light microscopic study}

Small parts of Lung tissue were fixed for 24 hours by 10 percent formalin buffered phosphate.The tissue was processed, sectioned with a microtome at 4-5 $\mu \mathrm{m}$ thickness then treated with Hematoxylin and Eosin stain $(\mathrm{H} \& \mathrm{E})^{[41]}$.

\section{Ultrastructural study}

Small lung portions of all groups were immediately fixed at $4{ }^{\circ} \mathrm{C}$ for $18-24 \mathrm{~h}$ in $3 \%$ glutraldehyde-formaldehyde, phosphate buffer rinsing, followed by 1 percent osmium tetroxide post-fixation. In a sequence of alcohols, the specimens were then dehydrated, washed in propylene oxide and eventually embedded in Epon epoxy resin. After that, an ultra-microtome trimmed the blocks, sectioning them with glass knives. Semi-thin sections $(1 \mathrm{~mm})$ have been treated with toluidine blue stain and examined on light microscope in order to choose the correct region for the ultrathin parts. The same ultra-microtome was used for cutting sections of ultrathin $(70-90 \mathrm{~nm})$ and then treated with uranyl acetate and lead citrate stain $^{[42]}$. Joel CX 100 transmission electron microscope, operated at an accelerating voltage of $60 \mathrm{kV}$, performed an examination of the stained sections.

\section{Statistical analysis}

Version 20 of the Social Sciences Statistical System (SPSS) for the Windows software system (SPSS Inc, Chicago, IL, USA) was used for analyzing data. All statistical comparisons were created according to one-way ANOVA method accompanied by post-hoc analysis, and the results were shown as mean \pm standard error (SE). A value of $P<0.05$ was rated significant.

\section{RESULTS}

Effect of Panax ginseng on body weight change of LCT- treated rats

Oral gavage of LCT $(61.2 \mathrm{mg} / \mathrm{kg} / \mathrm{day})$ for two months showed a very highly significant $(P<0.001)$ decrease in body weight change in comparison with normal control group. On the other hand, injection, intraperitoneally, with $\mathrm{G}(200 \mathrm{mg} / \mathrm{kg}$ b. wt. /day) caused a highly significant $(P<0.01)$ increase in body weight change when as compared to LCT- treated rats. While intra-peritoneal injection with $100 \mathrm{mg} \mathrm{G} / \mathrm{kg}$ b. wt. daily for 60 days showed a non-significant $(P>0.05)$ elevation in body weight change when in comparison with LCT- treated group. Body weight change of control groups treated with either tested doses of $\mathrm{G}$ did not show any difference from normal control group (Figure 1A).

Effect of Panax ginseng on relative lung weight of LCT-treated rats Relative lung weight exhibited a very highly significant $(P<0.001)$ reduction in LCT-treated rats in comparison with control group. Intra-peritoneal injection of both tested doses of $\mathrm{G}$ showed a highly significant $(P<0.01)$ elevation in relative lung in comparison with control group LCT-treated rats (Figure 1B).

\section{Effect of Panax ginseng on lung LPO and total thiol contents of LCT-treated rats}

As illustrated in (Figure 2A); lung LPO, calculated in nmol $(\mathrm{MDA}) / 100 \mathrm{mg}$ tissue, exhibited a very highly significant $(P<0.001)$ elevation in LCT-treated rats in comparison with control group. As a result of $G$ administration, MDA level decrease with varying significance. However, $200 \mathrm{mg} \mathrm{G}$ seemed to be more effective $(P<0.01)$ than $100 \mathrm{mg} \mathrm{G}(P<0.05)$ in decreasing MDA Level (Figure 2B).

LCT-treated rats exhibited a very highly significant $(P<0.001)$ reduction of lung T. thiol contents in comparison with control group. Otherwise, intra-peritoneal injection of both tested doses of $\mathrm{G}$ produced a significant $(P<0.05)$ elevation in $\mathrm{T}$. thiol contents when in comparison with LCT-treated rats as illustrated in (Figure 2B).

\section{Effect of Panax ginseng on lung catalase (CAT) and superoxide dismutase (SOD) activities of LCT- treated rats}

The effect of LCT administration on lung SOD and CAT activities are shown on (Figure 3). Its data recorded obviously showed a very highly significant $(P<0.001)$ reduction in activities of both SOD and CAT in LCT-administered group in comparison with 
control group. Concurrent with LCT administration, G elevated CAT activity with a very highly significance $(P<0.001)$ in both tested doses (Figure 3B). Regarding SOD (Figure 3A), $200 \mathrm{mg} \mathrm{G}$ appeared to be more potent $(P<0.001)$ than $100 \mathrm{mg} \mathrm{G}(P<0.05)$.

Effect of Panax ginseng on lung apoptotic p53 gene and protein expression levels of LCT-treated rats

As illustrated in (Figure 4A), mRNA expression of p53 in lung tissue of LCT-treated rats exhibited a very highly significant $(P<0.001)$ up regulation in comparison with control group. On the other side, intra-peritoneal coinjection with both of $\mathrm{G}$ tested doses induced a very highly significant $(P<0.001)$ down regulation of p53 mRNA expression levels as compared to rats received LCT only.

Protein expression level of apoptotic protein p53 in lung tissue of LCT-treated rats exhibited a very highly significant $(P<0.001)$ increase in comparison with control group. Intra-peritoneal injection of both tested doses of $\mathrm{G}$ concomitant with LCT produced very highly significant $(P<0.001)$ decrease in 553 protein expression level in comparison with LCT-administered rats as illustrated in (Figure 4B).

Effect of Panax ginseng on lung anti-apoptotic B-cell lymphoma-2 (Bcl-2) gene and protein expression level of LCT-treated rats

qPCR analysis of Bcl-2 gene expression in lung of LCT-treated rats exhibited a very highly significant $(P<0.001)$ down-regulation in comparison with control group. Simultaneous administration of both tested doses of $\mathrm{G}$ with LCT induced a very highly significant $(P<0.001)$ up-regulation of Bcl-2 mRNA expression levels in comparison with LCT-treated group (Figure 5A).

The result of Western blotting exhibited a very highly significant $(P<0.001)$ decrease in $\mathrm{Bcl}-2$ protein expression levels in lung tissues of LCT group in comparison with control group. Intra-peritoneal co-injection of $\mathrm{G}$ with LCT produced very highly significant $(P<0.001)$ elevation in protein expression levels in comparison with LCT group (Figure 5B).

\section{Effect of Panax ginseng on lung histolopathology of LCT-treated rats}

Microscopic examination of the lung of control, ginseng $100 \mathrm{mg} / \mathrm{kg} \mathrm{b}$. wt. and ginseng $200 \mathrm{mg} / \mathrm{kg} \mathrm{b}$. wt. /day respectively (Figures 6a, b, c) showed normal histological structure including blood vessels and clear alveoli with thin inter-alveolar septa, squamous type I pneumocytes, cuboidal type II pneumocytes and bronchioles.
LCT-treated group lung revealed obvious histopathological changes. Alveoli appeared collapsed with compensatory expansion of adjacent alveoli divided by thickened inter-alveolar septa (Figure 7a), remarkable hyperplasia of dilated bronchioles wall (Figures 7b, c), RBCs extravasation in bronchiolium lumen (Figure 7c), and mononuclear leukocytic infiltration in parenchyma additionally, blood vessels congested with thickened walls (Figures $7 \mathrm{a}, \mathrm{b}$ ).

Lung of LCT-treated rat treated with ginseng $100 \mathrm{mg} / \mathrm{kg} \mathrm{b}$. wt. /day revealed relative recovery except some collapsed alveoli (Figure 8a). Lung of LCT- treated rat treated with ginseng $200 \mathrm{mg} / \mathrm{kg} \mathrm{b}$. wt. /day showed great recovery and restoration of normal pulmonary tissue configuration (Figure 8b).

\section{Effect of Panax ginseng on lung ultrastructure of LCT-treated rats}

Electron microscopic observations of control group exhibited type 1 pneumocyte which appeared as a ell with a fsquamous clattened nucleus which occupied most of the volume of the cell and thin cytoplasm with few organelles (Figure 9a) and type 2 pneumocyte appeared cuboidal in shape with big spherical nuclei and chromatin condensed at the periphery. Membrane bounded lamellar bodies containing electron-dense secretions and several electrondense mitochondria appeared in its cytoplasm. Short microvilli were noticed projecting from the borders of type II penumocytes (Figure 9b).

The present study showed that the alveolar tissue of LCT-treated group revealed ultrastructural alterations including, cytoplasmic vacuolation, pyknotic nuclei, empty lamellar bodies and absence of microvilli of type 2 pneumocytes (Figures 10a, b). Type 1 pneumocytes revealed shrinkage in nucleus and vacuolated cytoplasm (Figure 10c). Inter-alveolar septum exhibited thickened (Figure 10d).

Injection of LCT-treated rats with $100 \mathrm{mg} \mathrm{G} / \mathrm{kg} . b . w t /$ day resulted in relative improvement in the constituents of the alveolar tissue. Partially empty lamellar bodies, short microvilli and normal nucleus of type 2 pneumocyte (Figure 11a). Type 1 pneumocyte appeared with normal flattened nucleus except some cytoplasmic vacuolation (Figure 11b). Inter-alveolar septum with normal thickness (Figure 11c).

While injection LCT-treated rats with $200 \mathrm{mg} \mathrm{G} / \mathrm{kg}$ b. wt /day restore normal shape of nuclei, lamellar bodies, mitochondria, border thickness and short microvilli (Figures 12 a,b,c). 
(A)
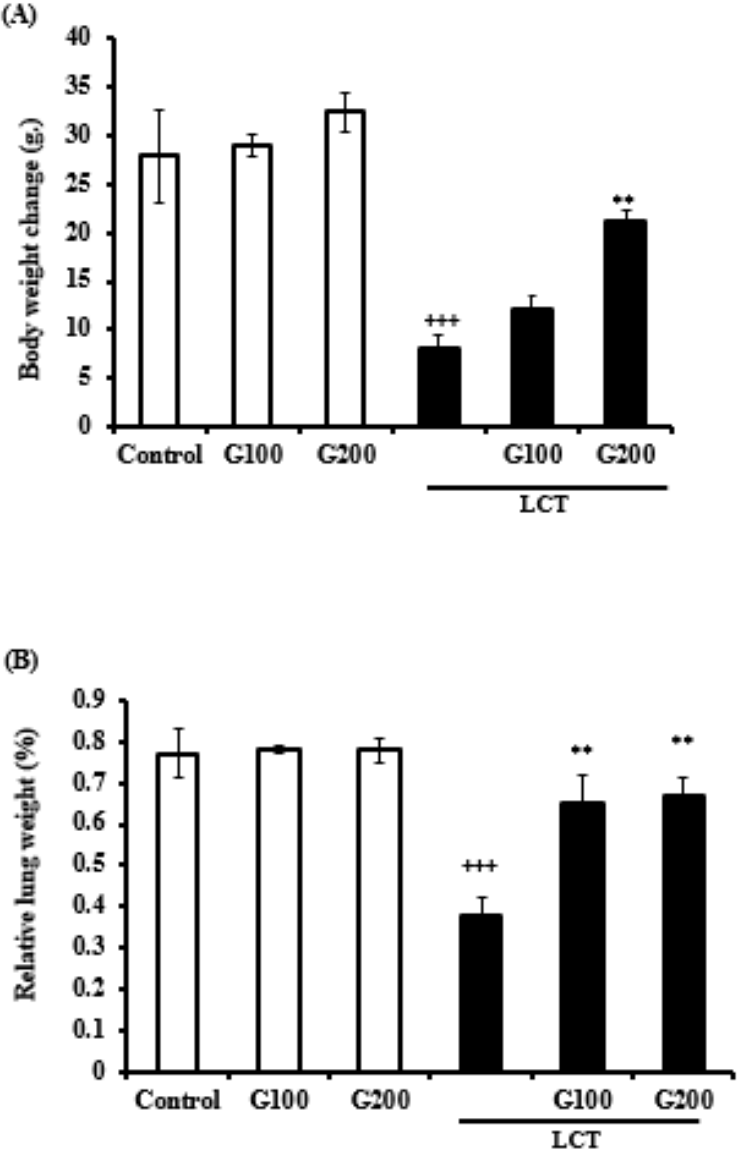

Fig. 1: Effect of Panax ginseng on lambada cyhalotherin-induced changes in (A) body weight change (g) and (B) relative lung weight (\%). The results were expressed as Mean $\pm \mathrm{SE}(\mathrm{N}=6)$. Where, G100, $100 \mathrm{mg}$ Panax ginseng; G200, $200 \mathrm{mg}$ Panax ginseng; LCT, lambada cyhalotherin administered rats. Values were considered significantly different at $+++P<0.001$ versus control group and $* * P<0.01$ versus LCT group.
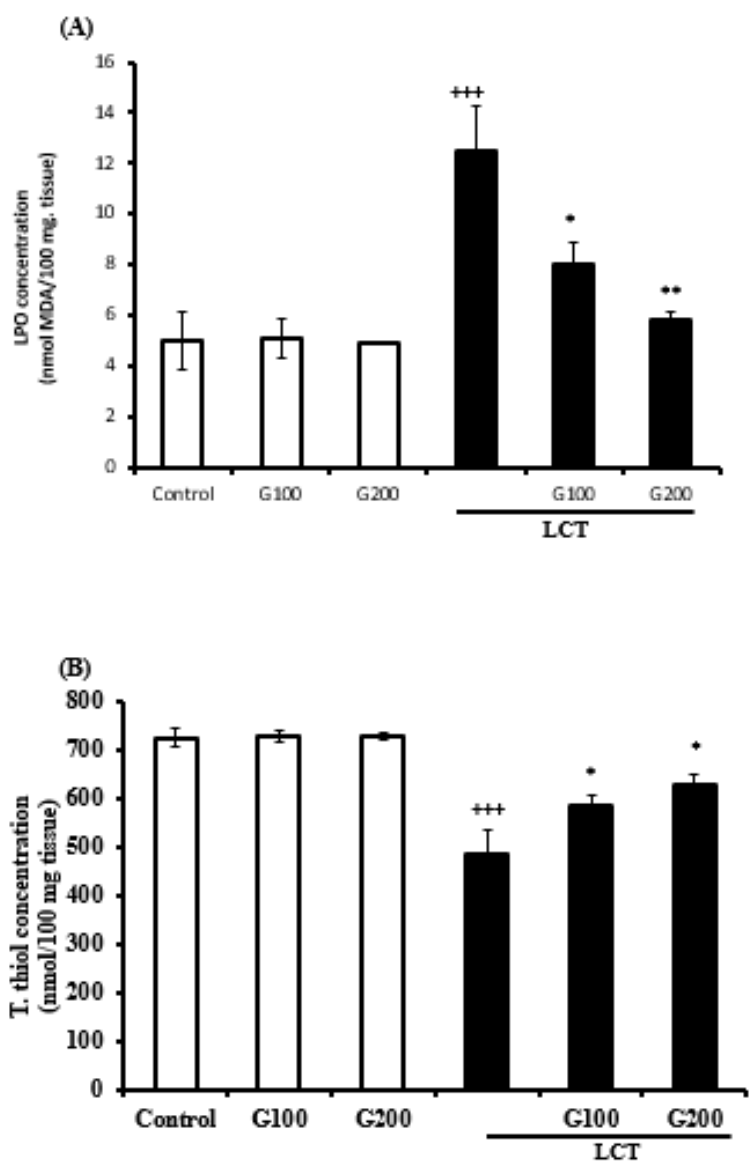

Fig. 2: Effect of Panax ginseng on lambada cyhalotherin-induced changes in lung (A) Lipid peroxidation products (LPO) and (B) Total thiol (T. thiol) concentrations. The results were expressed as Mean $\pm \mathrm{SE}(\mathrm{N}=6)$. Where, G100, 100 mg Panax ginseng; G200, 200 mg Panax ginseng; LCT, lambada cyhalotherin administered rats. Values were considered significantly different at $+++P<0.001$ versus control group and $* P<0.05, * * P<0.01$ versus LCT group 


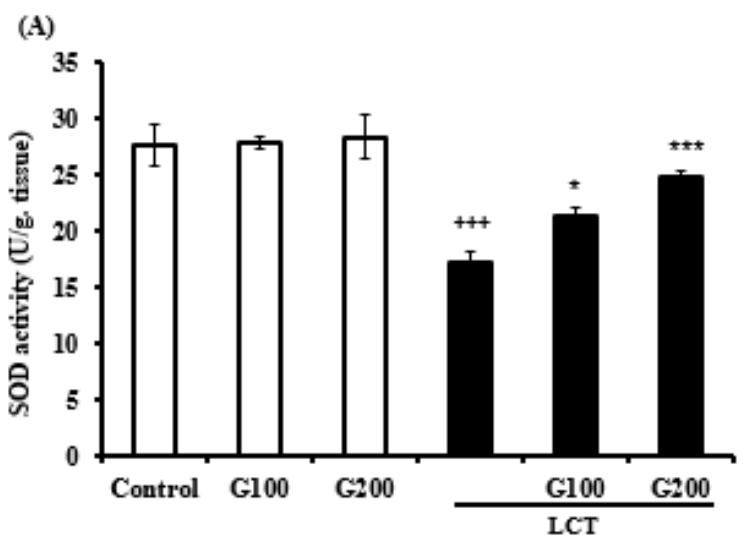

(B)

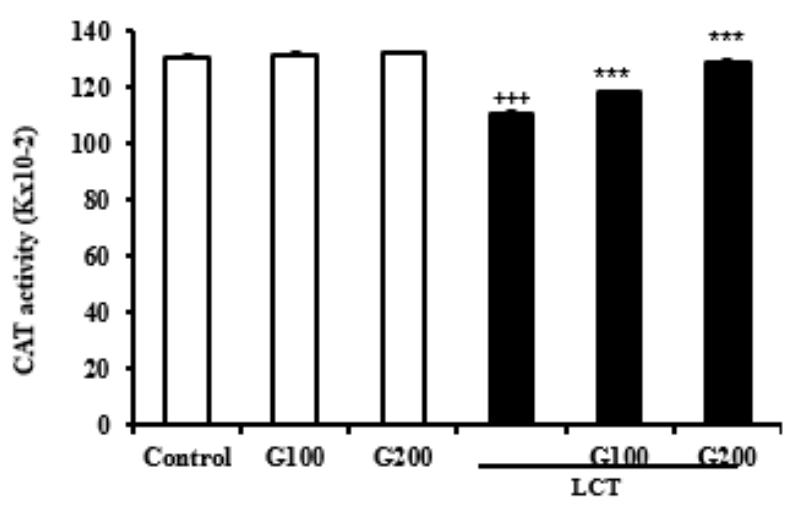

Fig. 3: Effect of Panax ginseng on lambada cyhalotherin-induced changes in lung enzymatic antioxidant defenses (A) Superoxide dismutase (SOD) and (B) Catalase (CAT) activities. The results were expressed as Mean \pm SE (N=6). Where, G100, 100 mg Panax ginseng; G200, 200 mg Panax ginseng; LCT, lambada cyhalotherin administered rats. Values were considered significantly different at $+++P<0.001$ versus control group and $* P<0.05,{ }^{*} * *<0.001$ versus LCT group.

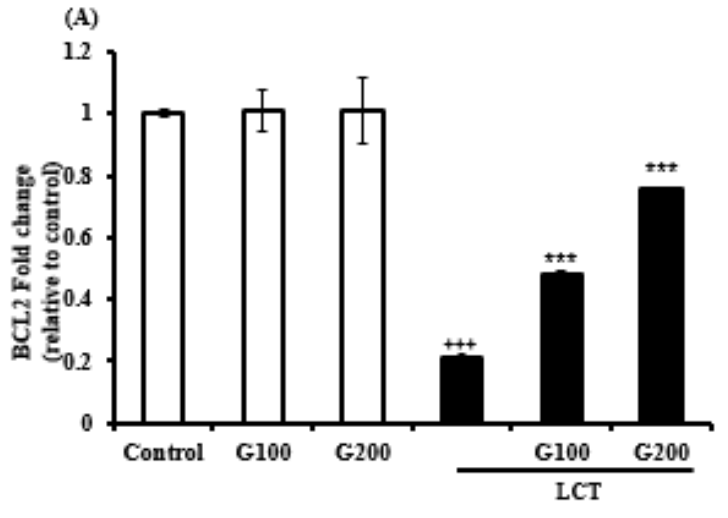

(B)

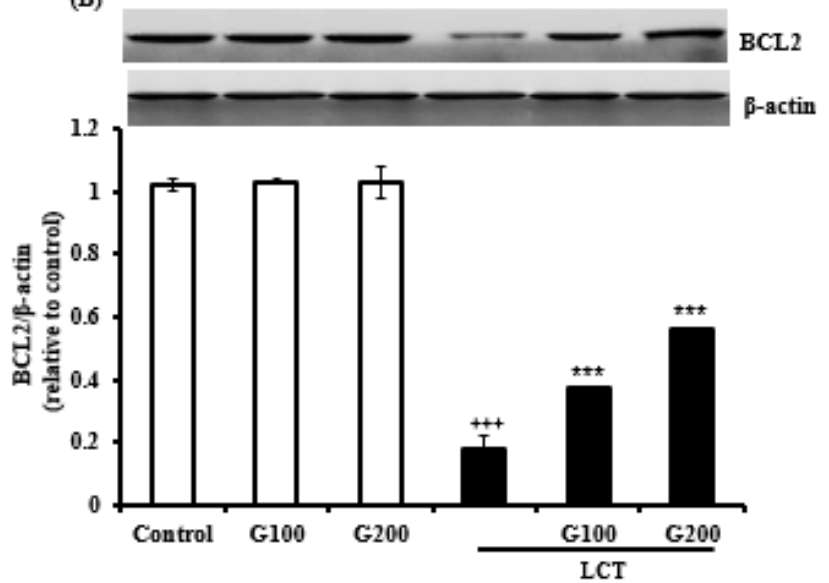

Fig. 4: lung (A) $\mathrm{BCL}_{2}$ mRNA and (B) $\mathrm{BCL}_{2}$ protein expression levels in control, G, LCT and LCT rats co-treated with G. The results were expressed as Mean $\pm \mathrm{SE}(\mathrm{N}=6)$. Where, $\mathrm{C}$, control group; G, Panax ginseng injected rats and LCT, lambada cyhalotherin administered rats. Values were considered significantly different $+++P<0.001$ versus control group and $* * * P<0.001$ versus LCT group. 

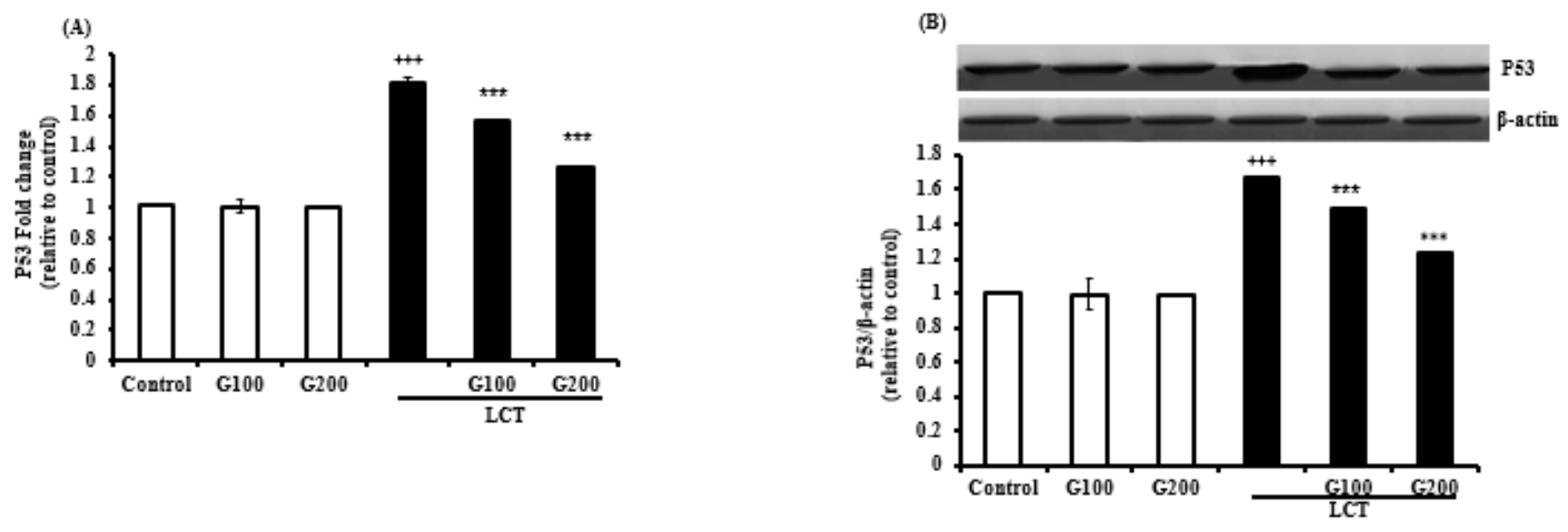

Fig. 5: lung (A) P53 mRNA and (B) P53 protein expression levels in control, G, LCT and LCT rats co-treated with G. The results were expressed as Mean \pm SE $(\mathrm{N}=6)$. Where, $\mathrm{C}$, control group; $\mathrm{G}$, Panax ginseng injected rats and LCT, lambada cyhalotherin administered rats. Values were considered significantly different $+++P<0.001$ versus control group and $* * * P<0.001$ versus LCT group.

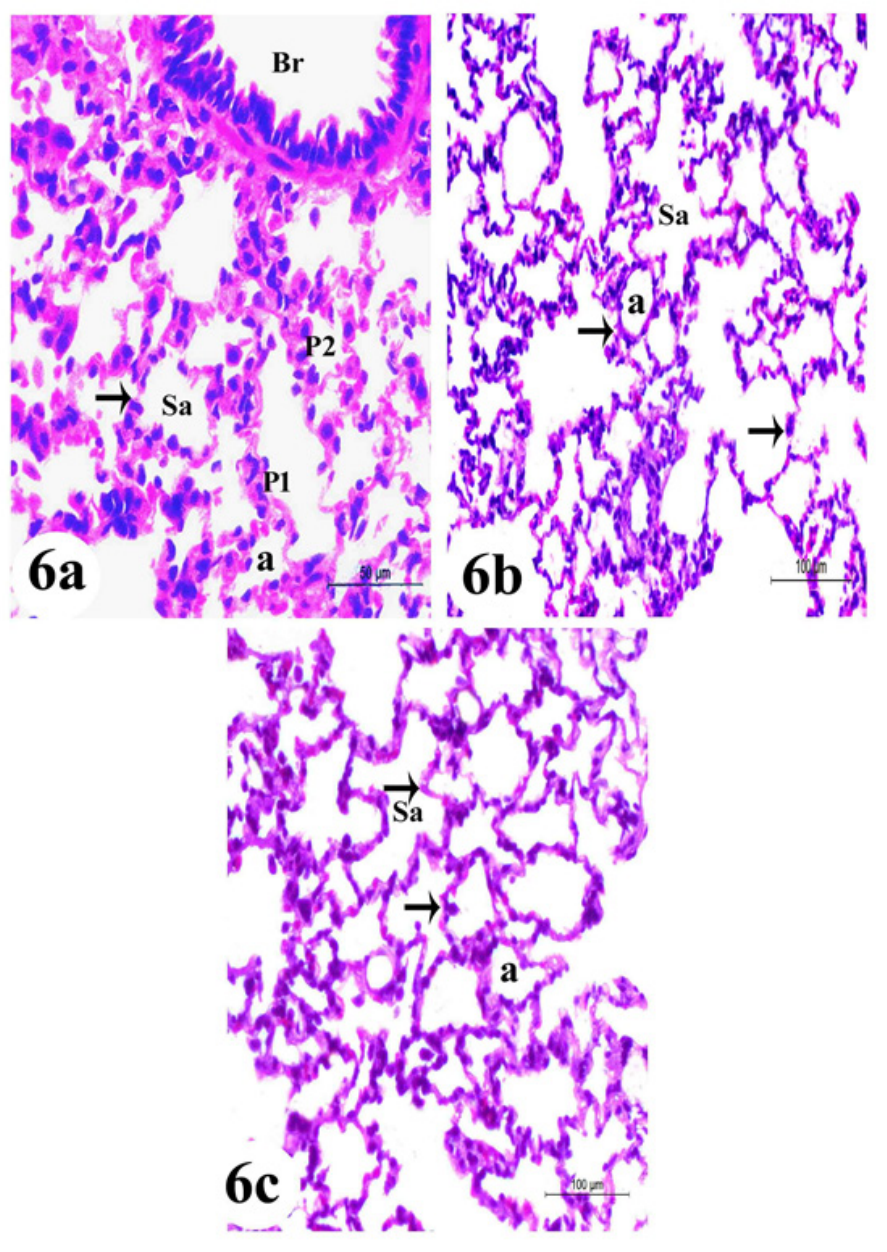

Fig. 6: Photomicrographs of sections of lung of control (a) and control ginseng groups (b \& c) 100 and $200 \mathrm{mg} / \mathrm{kg}$ b. wt. /day respectively stained with H\&E.: showing normal histological architecture of lung including alveoli (a) which are lined with type1 pneumocyte (P1) and type 2 pneumocyte (P2), thin interalveolar septum (arrows), bronchiole (Br), Saccule (Sa) (Scale bar $=50,100$ and100 $\mu \mathrm{m}$ respectively). 

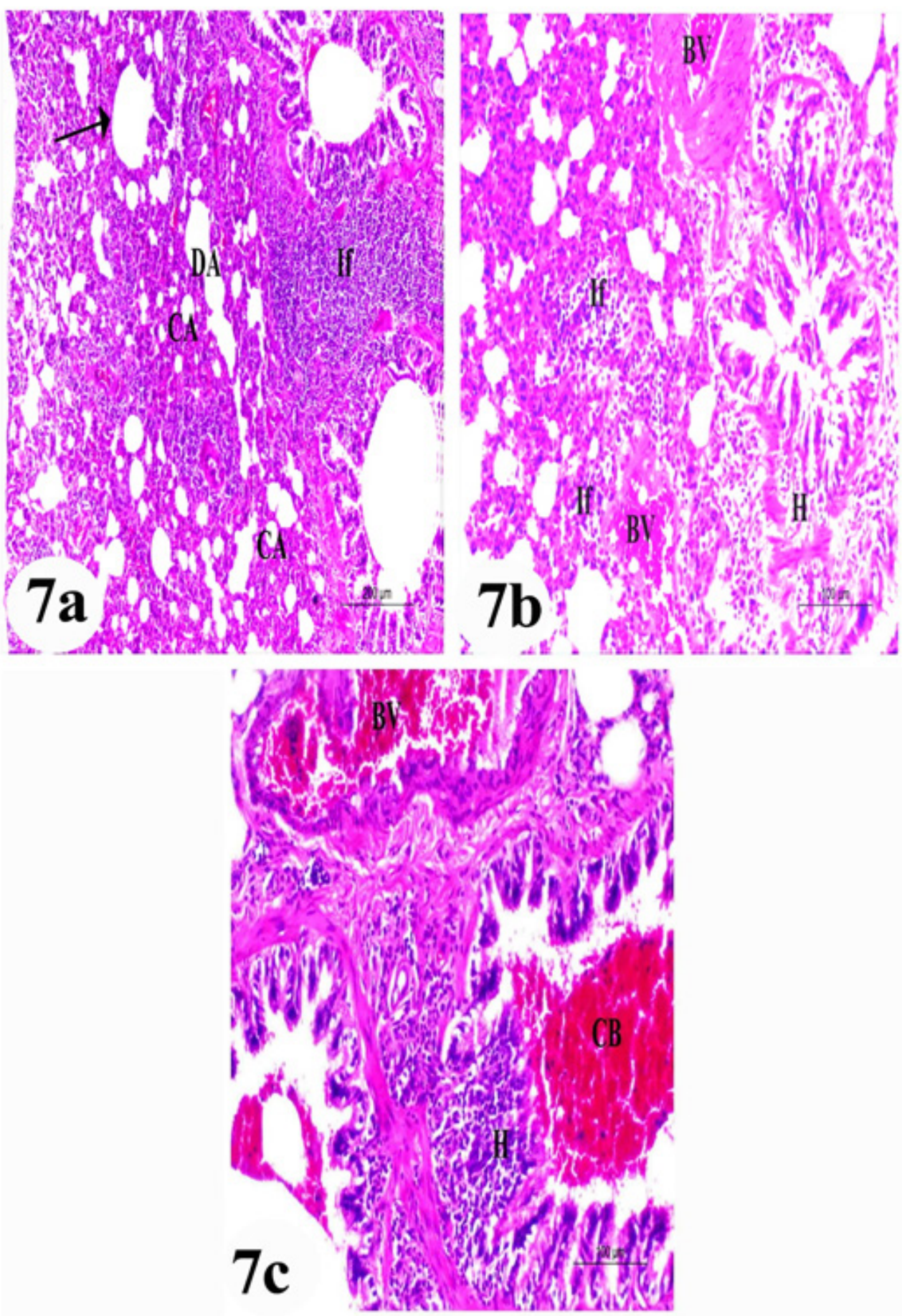

Fig. 7: Photomicrographs of sections of lung of LCT- intoxicated rats for 60 days stained with H\&E. (a): showing collapsed alveoli (CA) with compensatory expansion of adjacent alveoli (DA) separated by thickened inter-alveolar septum (arrow) and mononuclear leukocytic infiltration (If) in parenchyma (Scale bar $=200 \mu \mathrm{m})$. (b): showing congested blood vessels (BV) with thickened wall, marked hyperplasia $(\mathrm{H})$ of dilated bronchioles wall and mononuclear leukocytic infiltration (If) in parenchyma (Scale bar $=100 \mu \mathrm{m}$ ). (c): showing extravasation of red blood cells in the bronchiole lumen (CB), congested blood vessels (BV) with thickened wall and marked hyperplasia $(H)$ of dilated bronchioles wall (Scale bar $=100 \mu \mathrm{m})$. 


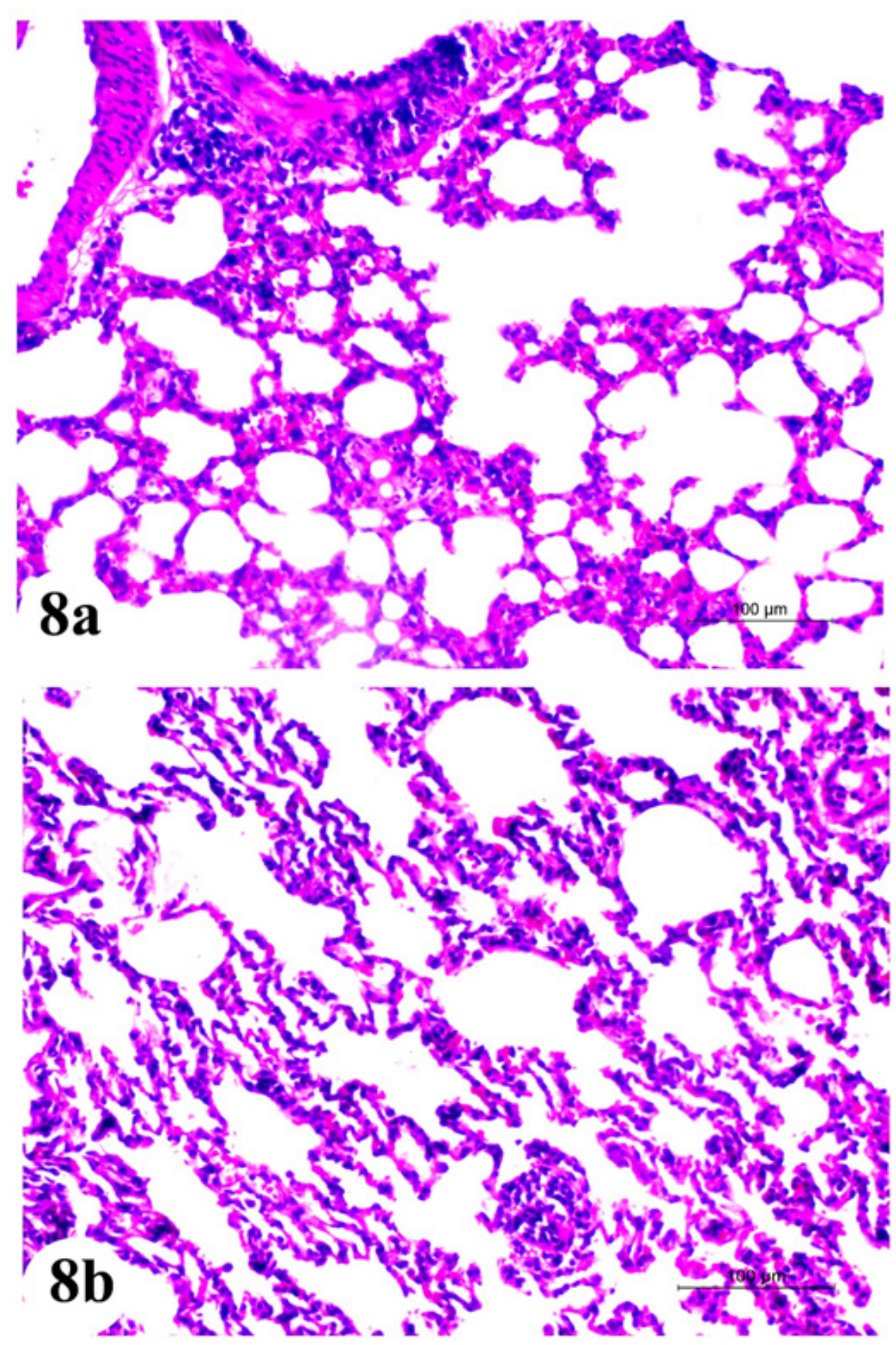

Fig. 8: Photomicrographs of sections of lung of treated rats stained with H\&E. (a): LCT plus ginseng $100 \mathrm{mg} / \mathrm{kg}$ b. wt. showing relative recovery except some collapsed alveoli (Scale bar $=100 \mu \mathrm{m})$. (b): LCT plus ginseng $200 \mathrm{mg} / \mathrm{kg}$ b. wt. group showing approximate regain of normal appearance of pulmonary tissue (Scale bar $=100 \mu \mathrm{m})$. 

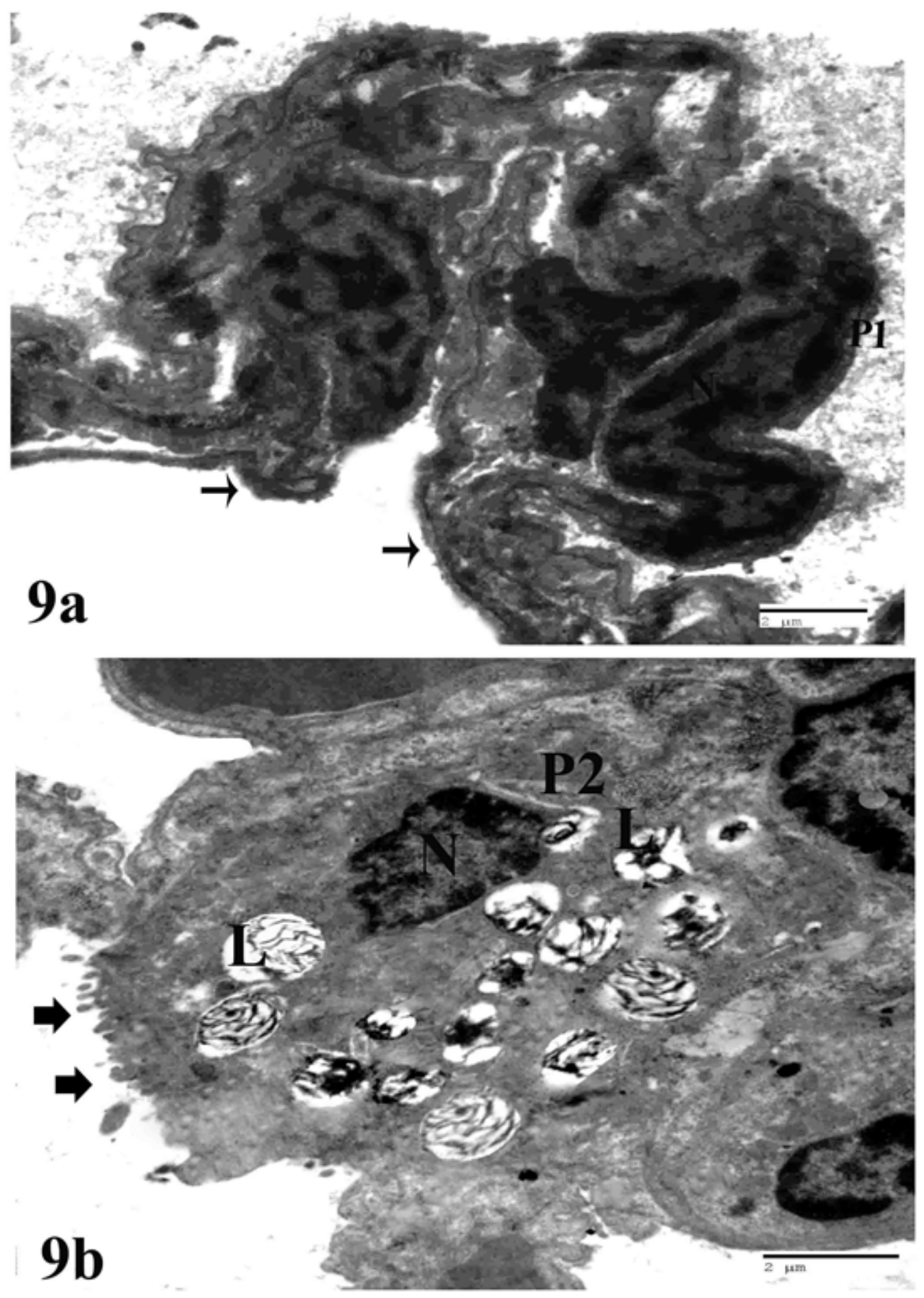

Fig. 9: Electron micrographs of a sections of lung of a control rats (a) Showing normal type 1 pneumocyte (P1) with flattened nucleus (N) and normal interalveolar septum (thin arrow) (Scale bar $=2 \mu \mathrm{m}$ ). (b) Showing normal type2 pneumocyte (P2) which is cuboidal in shape with normal lamellar bodies (L), short intact microvilli (thick arrow) and large nucleus $(\mathrm{N})($ Scale bar $=2 \mu \mathrm{m})$. 

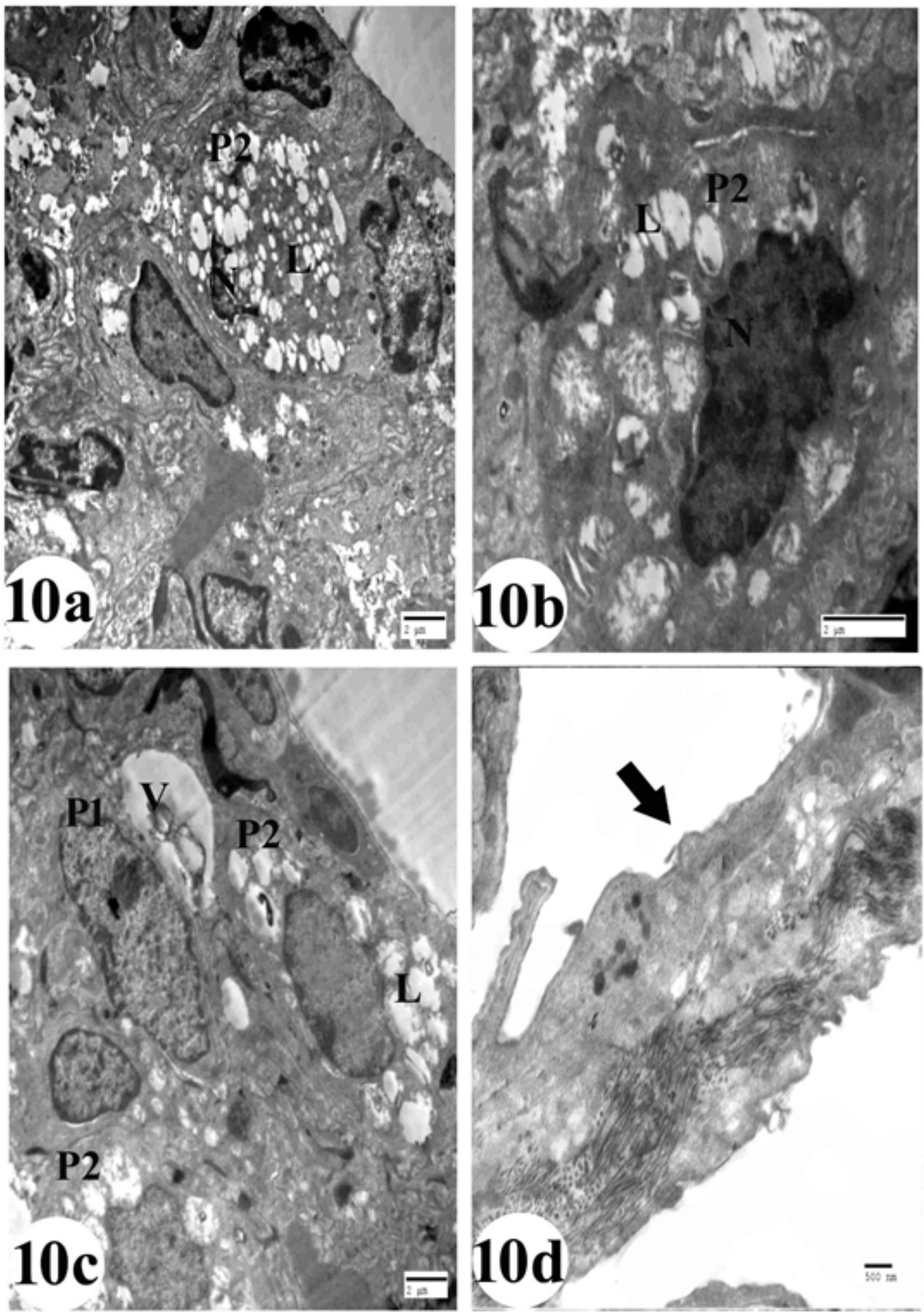

Fig.10: Electromicrographs of sections of lung of rats treated with LCT (a \& b) Showing abnormal type 2 pneumocyte (P2) with empty lamellar bodies (L) and shrinked pyknotic nucleus $(\mathrm{N})$ and lack of microvilli (Scale bar $=2 \mu \mathrm{m})$. (c) Showing abnormal type 1 pneumocyte $(\mathrm{P} 1)$. Notice vacuolated cytoplasm $(\mathrm{v})$ and damaged type 2 pneumocyte with empty lamellar bodies $(\mathrm{L})($ Scale bar $=2 \mu \mathrm{m})$. (d) Showing thickened inter-alveolar septum (thick arrow) $(\mathrm{Scale}$ bar $=2 \mu \mathrm{m})$. 

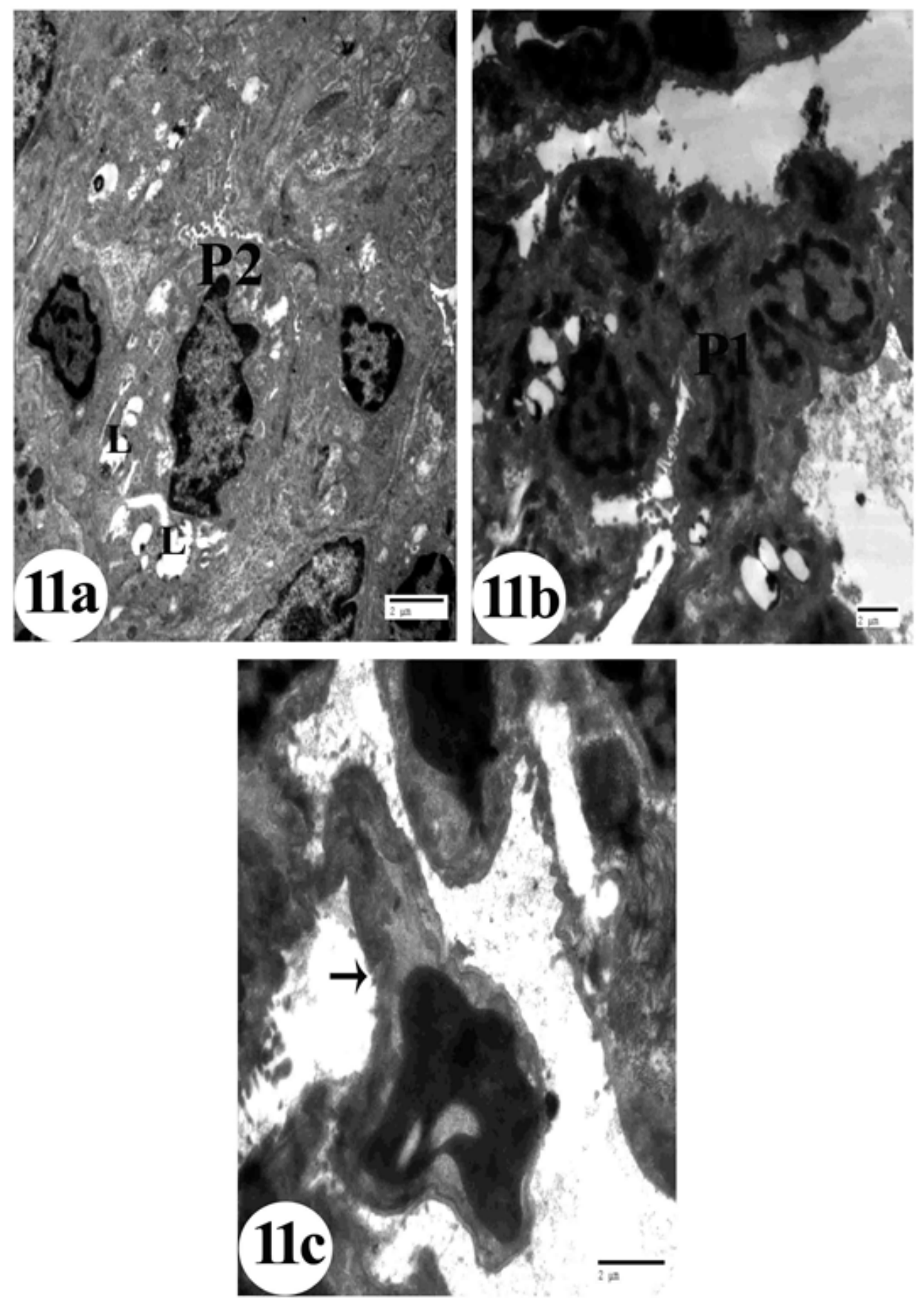

Fig. 11: Electron micrographs of a sections of lung of a LCT $+100 \mathrm{mg}$ ginseng/kg b. wt. /day treated rats (a) Showing type 2 pneumocyte (P2) except some empty lamellar bodies $(\mathrm{L})$ and few microvilli (Scale bar $=2 \mu \mathrm{m})$. (b) Showing type 1 pneumocyte $(\mathrm{P} 1)$ except some cytoplasmic vacuolation. $($ Scale bar $=2 \mu \mathrm{m})$. (c) Showing normal inter-alveolar septum (thin arrow) (Scale bar $=2 \mu \mathrm{m})$. 

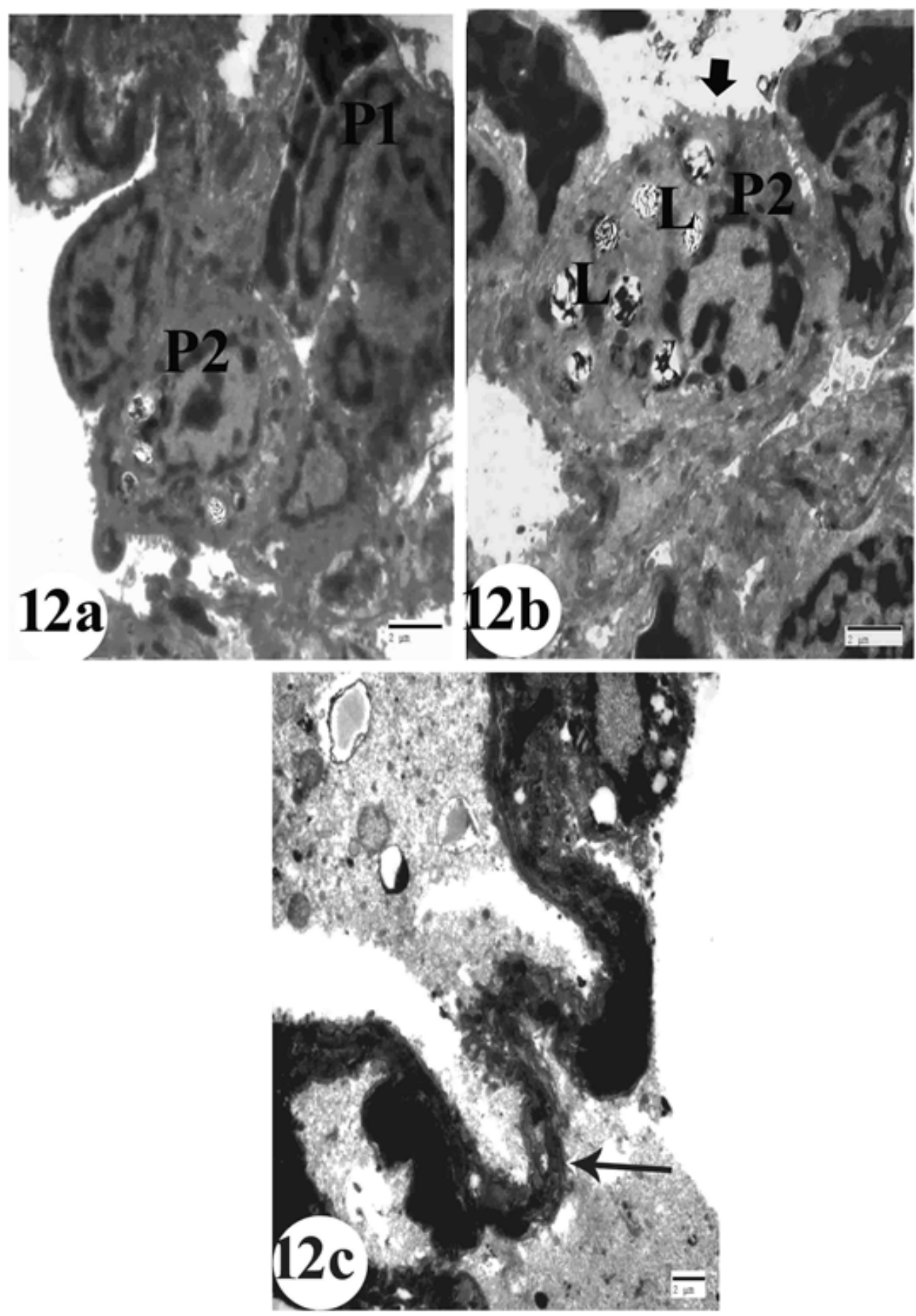

Fig. 12: Electron micrographs of a sections of lung of LCT $+200 \mathrm{mg}$ ginseng/kg b. wt. /day treated rats (a) Showing normal type 2 pneumocyte (P2) and normal type 1 pneumocyte $($ Scale bar $=2 \mu \mathrm{m})$. (b) Showing normal type 2 pneumocyte (P2) with normal lamellar bodies (L), intact microvilli (thick arrow) and large nucleus (Scale bar $=2 \mu \mathrm{m})$. (c) Showing normal inter-alveolar septum (thin arrow) (Scale bar $=2 \mu \mathrm{m})$ 


\section{DISCUSSION}

Despite the great benefits of pesticides in protecting agricultural crops, animals and humans from harmful pests and diseases vectors, they have extremely harmful effect on non-target creatures including human and other mammalian animals.Nevertheless, the public health effects of pesticide residues are yet to be fully understood. By increasing its use a precise evaluation of their hazards is required.

It is well documented that free radicals have a significant role in pesticide induced toxicity ${ }^{[17]}$. Pesticides may induce oxidative stress due to alteration in the status of the scavenging antioxidant enzymes, propagation of lipid peroxidation products ${ }^{[43]}$ and apoptosis that represent major contributors in lung damage. Thus, the present study determine the possible therapeutic potential of $\mathrm{G}$ toward pulmonary damage caused by LCT in rat model.

In our current study, body weight, relative weight of lung of LCT-treated rats were reduced that run in a good agreement with previous studies ${ }^{[44-49]}$. Kohner et al. ${ }^{[44]}$ observed that decreasing body weight and organs relative weight is one of the chronic effects of pyrithroids toxicity. In LCT-treated rats, the observed decrease can be related to hypophagia or loss of weight because of LCT's direct cytotoxicity ${ }^{[46]}$.

Many studies either In vitro or in vivo demonstrated that $\mathrm{G}$ decreases chemical, physical, and biological stress and maintain general vitality ${ }^{[50]}$. In our study treatment of LCT-treated rats with 100 or $200 \mathrm{mg} \mathrm{G} / \mathrm{kg}$ b. wt. /day increased body weight, relative weight of lungs. Qadir et $a l .{ }^{[51]}$ demonstrated that ginseng protect mice from body weight loss and improved kidney weight induced by gentamicin toxicity.

Oxidative stress has been described as losing balance between antioxidants and oxidants due to general elevation in ROS cellular levels ${ }^{[52]}$. It is known as risk factors for developing of diverse diseases ${ }^{[53]}$. ROS are known to induce oxidative damage to proteins, lipids, and $\mathrm{DNA}^{[54,55]}$. Consistent with its lipophilic nature ${ }^{[56]}$. In biological membranes LCT was found accumulated making oxidative damage and LPO which has been used widely as an oxidative stress marker. MDA is the main oxidation component of polyunsaturated peroxidized fatty acids thus elevated level of MDA is a LPO's powerful marker ${ }^{[57]}$. In the current study, LCT produced marked increase in lung tissues' MDA level. This suggests that increased LPO may be one of the valuable mechanisms associated with toxicity induced by LCT in rats.

Interestingly, $\mathrm{G}$ co-administration significantly protected lung tissues against LCT-induced LPO, suggesting its free radical scavenging action and the mechanisms of chain- breaking. Zhang et al. ${ }^{[26]}$ stated that LPO induced by iron- and hydrogen peroxide, via decomposition of unsaturated fatty acid, prevented by long-term administration of $G$ extract. $G$-extract's antioxidant effect could happen in both initiation stage and also at the propagation stage.

Furthermore, when an oxidative stress disorder strongly develops, the protection capacities against ROS becomes inadequate, in turn ROS often alter the antioxidant defense mechanisms, decrease T. thiol intracellular concentration of, disrupt antioxidant enzymes activity e.g., CAT and SOD and elevate MDA levels ${ }^{[58,59]}$. Indirectly, these indicate increased development of oxygen-free radicals.

Highly reactive oxygen metabolites, particularly hydroxyl radicals $(\cdot \mathrm{OH})$, react with unsaturated fatty acids of membrane phospholipid components producing $\mathrm{MDA}^{[60]}$.

The role of CAT and SOD in the scavenging of ROS is well known. SOD act as a catalyst in the degradation of the superoxide radicals $\left(\mathrm{O}^{-}{ }^{-}\right)$to hydrogen peroxide $\left(\mathrm{H}_{2} \mathrm{O}_{2}\right)$, while CAT makes reduction to $\mathrm{H}_{2} \mathrm{O}_{2}$ into water $\left(\mathrm{H}_{2} \mathrm{O}\right)$ and oxygen molecule $\left(\mathrm{O}_{2}\right)$ to inhibit oxidative stress and in Preserving homeostasis in cell. In the current study, SOD and CAT activities were decreased markedly in lung of LCT-treated rats.Both CAT and SOD function together to remove ROS, and minor physiological concentration differences may have a significant impact on cellular lipid, protein and DNA resistance to oxidative damage ${ }^{[61]}$. In the LCT group, low SOD levels may attributed to this enzyme consumption because of elevated oxidative stress in lung tissue.

Thiols are the organic compounds that contain a sulphydryl group. Of all the antioxidants present in the body, thiols constitute the main part of the total antioxidants in the body, and they play a major role in defending against ROS.

Thiols consisting of both intracellular and extracellular thiols in free form as oxidized or reduced glutathione, or protein-bound thiols ${ }^{[62]}$. In the current study, low levels of total thiol is lung of LCT-treated rats matching with other endogenous oxidative stress-related markers (SOD, CAT) produced clear indications that the pathogenesis of LCT- lung toxicity involves oxidative stress.

The antioxidant properties of $\mathrm{G}$ are well-documented. $\mathrm{G}$ possesses antioxidant activity through improving the expression of antioxidant enzyme gene that related to ROS scavenging ${ }^{[63]}$. In the present study, co-administration of $G$ with LCT induced a significant reduction in the mean value of MDA and a marked elevation in the mean values of antioxidant enzymes (SOD and CAT) activities and total thiols in lung as compared with LCT-treated group. Similarly, Al-Harbi et al.$^{[64]}$ stated that $\mathrm{G}$, as an antioxidant, reduced level of MDA and elevated activities of CAT and SOD induced by fipronil. Also, Diab et al ${ }^{[65]}$ reported that $\mathrm{G}$ administration reduced level of MDA and elevated CAT and SOD activities in chlorpyrifos and profenofos- treated animals.

Matching with reduced endogenous antioxidants, the current study showed marked up-regulation in mRNA 
and protein expression levels of lung p53 (Proapoptotic gen) accompanied with down-regulation in mRNA and protein expression levels of Bcl2 (anti-apoptotic gen) in LCT-treated rats in comparison with control group. These genes play a major role in apoptosis regulation ${ }^{[66,67]}$. In line with the current results, Gupta et al. ${ }^{[68]}$ demonstrated that Bcl2 protein was decreased in corneal epithelial cells of human exposed to Allethrin (type 1 pyrithroid). Also Bcl2 protein expression was decreased in brain of deltamethrin (type 2 pyrithroid) treated rats ${ }^{[69,70]}$ in splenocytes ${ }^{[71]}$. These obtained results proposed activation of the apoptotic pathway via upregulation of p53 gene and protein as well as $\mathrm{Bcl} 2$ gene and protein down regulation could be involved in lung damage induced by LCT.

In normal condition, apoptosis is responsible for tissue remodeling during the development and turnover of normal tissue for better functioning of the body but an uncontrolled apoptosis causes excessive damage of tissue. LCT-treated rats showed ROS generation, DNA fragmentation and apoptosis ${ }^{[22,72,73]}$. The mechanism of apoptosis induced by LCT has been proposed to be linked with oxidative stress and mitochondrial pathway activation of a transcription factor, nuclear factor-kappa $\mathrm{B}(\mathrm{NF}-\mathrm{KB})$ is a crucial activator of inflammatory, immune and apoptosis genes ${ }^{[52]}$. Activation of $\mathrm{NFKB}$ induces cell proliferation to decrease and apoptosis to increase by DNA damage induced by ROS and activation of p53. Activated p53 due to LCT oral exposure additionally stimulates the intrinsic mitochondrial apoptotic pathways responding to DNA damage by stimulating pro-apoptotic proteins (Bax, caspase-3) expression, down regulates Bcl-2 expression and switches the balance to pro apoptotic effects ${ }^{[52]}$. Injection of $\mathrm{G}$ concomitant with LCT produced down regulation of $\mathrm{p} 53$ mRNA and protein expression in lung tissue in comparison with LCT group. SO, we can relate the improved rate of apoptosis in co-treated groups to antioxidant activity of $\mathrm{G}$ and the ROS scavenging, suppression of NF-KB activation, interleukin (IL-1 $\beta$ ) and release of cytokines. Matching with Cheng et al. ${ }^{[74]}$ who reported that $\mathrm{G}$ inhibits interleukin (IL-1 $\beta$ )-induced apoptosis in human chondrocytes. Previous research has shown that ginsenosides Rg3 inhibit apoptosis of endothelial cell by elevation the expression of BAX and reducing Bcl-2 in cells of prostate cancer ${ }^{[75,76]}$. $\mathrm{G}$ decreased gene expression of pro-apoptotic proteins p53 and caspase-3, while elevated anti-apoptotic Bcl2 expression in neuroblastoma cells suggested protective effects of $\mathrm{G}$ against cell death in oxidatively stressed brain cells $^{[77]}$. Also, G suppresses TNF- $\alpha /$ IFN-c-induced thymus and activation-regulated chemokine (TARC) expression through NF-kB dependent signaling in HaCaT cells. G improved 2, 4-dinitrochlorobenzene (DNCB)-induced dermatitis severity, serum levels of $\operatorname{IgE}$ and TARC, and mRNA expression of TARC, TNF- $\alpha$, IFN-c, IL-4, IL-5, and IL-13 in mice. G suppressed TNF- $\alpha$ /IFN-c induced NF-KB activation ${ }^{[78]}$.

The current histopathological investigations demonstrated that the administration of the LCT to adult male rats for 60 days induced variable degenerative changes in the pulmonary tissue in comparison with normal control group. These histopathological observations represented by severe damage in alveoli as collapsed alveoli divided by remarkably thickened inter-alveolar septa with compensatory expansion of adjacent alveoli. Bronchiolitis manifested by remarkable hyperplasia of dilated bronchioles wall and extravasation of RBCs in the bronchiole lumen. Blood vessels showed congestion and thickening in wall with mononuclear leukocytic infiltration in the surrounding tissue beside to numerous hyperemia in some tissues. These findings are in line with Mohi-Eldin et al. ${ }^{[2]]}$ in rat model and Abdul Basir et al. ${ }^{[9]}$ in rabbit model. Also, similar histopathological observations have been reported by Sheikh et al. ${ }^{[79]}$ on the effect of cypermitherin on lung tissue of mice model and by Arafa et al..$^{[23]}$ in rat model.

In our study LCT-treated rats exhibited pulmonary ultrastructural alterations characterized by cytoplasmic vacuolation and shrinkage nucleus in both type I and type II pneumocytes, empty lamellar bodies, absence of microvilli of type II pneumocytes and thickening of inter alveolar septum.

Type I pneumocytes which cover about 95 percent of the lung's inner surface and responsible for gas exchange ${ }^{[80]}$. Like neurons, type I pneumonocytes are considered to have lost the capacity for mitosis. Cells of destroyed pneumocytes type I are replaced by cells of pneumocytes type II ${ }^{[81]}$. According to our ultrastructural observation Type I pneumocytes revealed shrinked nucleus and vacuolated cytoplasm that impair its structure and function in gas exchange Type II includes characteristic lamellar inclusions, which are surfactant's source, the material in charge of alveolar surface tension modifications ${ }^{[82]}$. Degenerative alterations in pneumocytes type II were observed as vacuolation and reduced surfactant material in their lamellar bodies ${ }^{[23,83]}$. There is also evidence that type II pneumocytes produce a diverse range of materials participating in alveolar structure and defense as $\alpha 1$ antitrypsin and fibronectin that can inhibit the proliferation of lymphocytes and improve macrophage functioning in the alveolar septa ${ }^{[84,85]}$.

The ultrastructural alterations in pneumocytes type II, Possibly associated with LPO effect on phospholipids of membrane, were associated with surfactant secretion impairment and turnover. This proposition was also confirmed by lamellar body residues existence, that may participate to the functional effect on $\mathrm{O}_{2}{ }^{[86]}$. These alterations in pneumocytes type II are identical to apoptosis and necrosis picture presented in several studies ${ }^{[87,88]}$ because of an enhanced production of TNF- $\alpha$ and its resultant activation of the FASL/FAS signaling pathway[89].

Thickened inter alveolar septum was similar to earlier finding of arafa et al. ${ }^{[23]}$ reporting that $\alpha$-CYP-treated lung exhibited elevated alveolar wall thickness which can be rationalized by increased deposition of extracellular matrix 
proteins and endothelial hyperproliferation ${ }^{[90,91]}$ and related with low elasticity and respiratory gases exchange ${ }^{[92]}$. This may be linked to the ROS accumulation in lung due to elevated LPO.

In the current study, treatment of LCT-treated rats with $\mathrm{G} 100 \mathrm{mg} / \mathrm{kg}$ b. wt. /day and $200 \mathrm{mg} / \mathrm{kg}$ b. wt. /day plus LCT protected lung of LCT pulmonary toxicity and maintain approximately the normal histological structure matching with similar previous studies. According to Mohi El-Din et al. ${ }^{[21]} \mathrm{G}$ showed a reduction lung sensitivity against LCT-induced toxicity, in comparison with rats treated with LCT only, represented by bronchial wall with moderate hyperplasia and inflammatory cells clearance from the lumen.

\section{CONCLUSION}

The current study reported that $\mathrm{G}$ has shown therapeutic efficacy against LCT-induced histopathological and ultrastructural lung damage in rats. Moreover, the mechanisms sharing in its therapeutic efficacy involved free radicals scavenging, enhancing the antioxidants status and anti-apoptotic properties were shown.

Further investigations are needed to illustrate the accurate molecular mechanism of $\mathrm{G}$ against LCT-induced lung toxicity.

\section{CONFLICT OF INTERESTS}

There are no conflicts of interest.

\section{REFERENCES}

1. Saillenfait AM, Ndiaye D, Sabaté JP. Pyrethroid: exposure and health effects-an update. Int. J. Hyg. Environ. Health 2015; 218: 281-292.

2. Mulambalah CS, Siamba DN, Ngeiywa MM, Vulule JM. Evaluation of lambda-cyhalothrin persistence on different indoor Surfaces in a malaria epidemic-prone area in Kenya. J. boil. Sci. 2010; 5:258-263

3. Soderlund DM, Clark JM, Sheets PL, Mullin LS, Piccirillo VJ, Sargent D. Mechanisms of pyrethroid neurotoxicity: implications for cumalative risk assessment. Toxicology 2002; 171:3-59.

4. Singh A and Srivastava VK. Toxic effect of synthetic pyrethroid permethrin on the enzyme system of the freshwater fish Channa striatus. Chemosphere 1999; 39, 1951-1956.

5. Kale M, Rathore N, John S, Bhatnagar D. Lipid peroxidative damage on pyrethroid exposure and alterations in antioxidant status in rat erythrocyte: a possible involvement of reactive oxygen species; Toxicol. Lett. 1999; 105: 197-205.

6. Abdul-Hamid M, Moustafa M, Asran AA, Mowafy L. Cypermethrin-induced histopathological, ultrastructural and biochemical changes in liver of albino rats: The protective role of propolis and curcumin. Beni- suef. Univ. J. Appl. Sci. 2017; 6(2): 160-173.

7. Al-Sarar AS, Abobakr Y, Bayoumi AE, Hussein HI, Al-Ghothemi M. Reproductive Toxicity and Histopathological Changes Induced by Lambda-Cyhalothrin in Male Mice. Environ. Toxicol. 2012; 750: 762.

8. Stoyanova S, Yancheva V, Iliev I, Vasileva T, Bivolarski V, Velcheva I, Georgieva E. Biochemical, histological and histochemical changes in Aristichthys nobilis Rich. Liver exposed to thiamethoxam. Periodicum Biologorumol. 2016; 118(1): 29-36.

9. Abdul Basir, Khan A, Mustafa R, Khan MZ, Rizvi F, Mahmood F, Yousaf A. Toxicopathological effects of lambda-cyhalothrin in female rabbits (Oryctolagus cuniculus) Hum. and Exp. Toxicol. 2011; 591-602.

10. Davies CR, Lanos-Cuentas EA, Campos P, Monge J, Leon E, Canales J. Spraying houses in the Peruvian Andes with lambda-cyhalothrin protects residents against cutaneous leishmaniasis. Trans. R. Soc. Trop. Med. Hyg. 2000; 94, 631-636.

11. Kroeger A, Villegas E, Ordoñez-Gonzalez J, Pavon E, Scorza JV. Prevention of the transmission of Chagas' disease with pyrethoidimpregnated materials. Am.J. Trop. Med. Hyg. 2003; 68, 307-311.

12. Turgut C, Ornek H, Cutright TJ. Determination of pesticide residues in Turkey's table grapes: the effect of integrated pest management, organic farming, and conventional farming. Environ. Monit. Assess. 2011; 173:315-323.

13. Bissacot DZ and Vassilieff I. Pyrethroid residues in milk and Blood of dairy cows following single topical applications. Vet. Hum. Toxicol.1997; 39: 6-8.

14. Muhammad F, Akhtar M, Rahman ZU, Farooq HU, Khaliq T, Anwar MI. Multi-residue determination of pesticides in the meat of Cattle in Faisalabad- Pakistan. Egypt. Acad. J. biolog. Sci. 2010; 2 (2): 19-28.

15. Oliveira C, Vassilieff VS, Vassilieff I. Residues and placental on oxidative stress and cardiac diseases. Mid. East. Pharmac. 2002; 10:8-9.

16. Metwally HG, Abd-Ellah HF, Shaheen NEM, Afifi MSH, Al-Zail NI. Role of Mesenchymal stem cells in the treatment of testicular toxicity induced by Lambda-Cyhalothrin in Rats. Wulfenia journal 2017; 24(10): 108-138.

17. Sankar P, Telang AG, Manimaran A. Protective effect of curcumin on cypermethrin-induced oxidative stress in Wistar rats. Exp. Toxicol. Pathol. 2012; 64:487- 493. 
18. Ames BN, Shigenaga MK, Hagen TM. Oxidants, antioxidants, and the degenerative diseases of aging; Proc. Natl. Acad. Sci. U. S. A. 1993; 90: 7915-7922.

19. Chung HY, Kim HJ, Kim KW, Choi JS, Yu BP. Molecular inflammation hypothesis of aging based on the anti-aging mechanism of calorie restriction. Microsc. Res. Tech. 2002; 59: 264-272.

20. Muhammad F, Akhtar M, Rahman ZU, Javed I, Anwar MI. Role of veterinarians in providing residue free animal food; Pak Vet. J. 2009; 29:42-46.

21. Mohi-Eldin MM, Mostafa AM, Abd- El kader AA. Experimental studies on the effect of (Lambda-Cyhalothrin) insecticide on lungs and the ameliorating effect of plant extracts (Ginseng (Panax Ginseng) and garlic (Allium sativum L.) On asthma development in albino rats. BMC. Res. Notes. 2014; 7: 243.

22. Ragothaman R. Toxicopathology of cypermethrin in rats. Mvsc Thesis, 1991. Tamil Nadu University of Veterinary and Animal Sciences, Chennai.

23. Arafa MH, Mohamed DA, Atteia HH. Ameliorative effect of N-Acetyl cysteine on Alpha-Cypermethrin-induced pulmonary toxicity in male rats. Environ. Toxicol. 2015; 30(1):26-43.

24. Attele AS, Wu JA, Yuan CS. Ginseng pharmacology: Multiple constituents and multiple actions. Biochem. Pharmacol. 1999; 58(11):1685-1693.

25. Kim H, Chen X, Gillis CN. Ginsenosides protect pulmonary vascular endothelium against free radical-induced injury. Biochem. Biophys. Res. Commun.1992; 189(2):670-676.

26. Zhang D, Yasuda T, Yu Y, Zheng P, Kawabata $\mathrm{T}$, Ma Y. Ginseng extract scavenges hydroxyl radical and protects unsaturated fatty acids from decomposition caused by iron-mediated lipid peroxidation. Free Radic. Biol. Med. 1996; 20(1):145-150.

27. Wenzel SE, Szefler SJ, Leung DYM, Sloan SI, Rex MD, Martin RJ. Bronchoscopic evaluation of severe asthma: persistent inflammation associated with high dose glucocorticoids. Am. J. Respir. Crit. Care Med. 1997; 156:737-743.

28. Scaglione F, Weiser K, Alessandria M. Effects of the standardized ginseng extract $G 115 \AA$ in patients with chronic bronchitis: a nonblinded, randomised, comparative pilot study. Clin. Drug Invest. New Zealand, 2001; 21: 41-45.

29. Gross D, Shenkman Z, Bleiberg B, Dayan M, Gittelson M, Efrat R. Ginseng improves pulmonary functions and exercise capacity in patients with COPD. Monaldi. Arch. Chest. Dis. 2002; 57:242-246.
30. Lee CS, Lee JH, Oh M, Choi KM, Jeong MR, Park JD, Kwon DY, Ha KC, Park E, Lee N, Kim SY, Choi EK, Kim MG, Chae SW. Preventive effect of korean red ginseng for acute respiratory illness: a randomized and double-blind clinical trial. J Korean Med Sci. 2012; 27(12): 1472-1478.

31. Lee JH, Min DS, Lee CW, Song, KH, Kim YS, Kim HP. Ginsenosides from Korean Red Ginseng ameliorate lung inflammatory responses: Inhibition of the MAPKs/NF- $\kappa \mathrm{B} / \mathrm{c}-\mathrm{Fos}$ pathways. JGR. 2017; 290 S1226-8453(16)30276-7. doi: 10.1016/j.jgr.2017.05.005.

32. Yousef IM and Hussien HM. Cisplatin-induced renal toxicity via tumor necrosis factor- $\alpha$, interleukin 6, tumor suppressor P53, DNA damage, xanthine oxidase, histological changes, oxidative stress and nitric oxide in rats:Protective effect of ginseng. Food Chem. Toxicol. 2015; 78: 17-25.

33. Ben-Abdallah F, Fetoui H, Zribi N, Fakhfakh F, Keskes L. Quercetin Attenuates Lambda CyhalothrinInduced Reproductive Toxicity in Male Rats. Environ Toxicol. 2011; 28(12):673-680.

34. Preuss, H.G., Jarrel, S.T., Scheckenobach, R., Lieberman, S., Anderson, R.A., 1998. Comparative effects of chromium vanadium and Gymnemasylvestre on sugarinduced blood pressure elevations in SHR. J. Am. College Nutr. 17 (2), 116123.

35. Koster JF, Biermond P, Swaak AJG. Intracellular and extracellular sulphhydryl levels in rheumatoid arthritis. Annals of the Rheumatic Diseases 1986; 45:44-46.

36. Marklund $\mathrm{S}$ and Marklund $\mathrm{G}$. Involvement of superoxide anion radical in the autooxidation of pyrogallol and convenient assay for superoxide dismutase. Eur. J. Biochem. 1974; 47:469-474.

37. Cohen C, Dembiec D, Marcus J, Measurement of catalase activity in tissue extracts. Journal of Analytical Biochemistry 1970; 34:30-38.

38. Mahmoud AM. Hesperidin protects against cyclophosphamide-induced hepatotoxicity by upregulation of PPAR $\gamma$ and abrogation of oxidative stress and inflammation. Can. J. Physiol. Pharm. 2014; 92:717-724.

39. Livak KJ and Schmittgen TD. Analysis of relative gene expression data using real-time quantitative PCR and the 2(-Delta Delta C(T)). Method. $2011 ; 25: 402-408$.

40. Mahmoud AM, Germous MO, Alotaibi MF, Hussein O. Possible involvement of Nrf2 and PPAR gamma upregulation in the protective effect of umbelliferone against cyclophosphamideinduced hepatotoxicity. Biomed Pharmacother 2017; 86:297-306. 
41. Bancroft, J.D., Gamble, M. Theory and Practice of Histological Techniques, 5th ed. Churchill Livingstone, London 2002: 109-136.

42. Bozzola, J.J., Russell, L.D. 1999. Electron Microscopy: Principles and Techniques for Biologists. Jones and Bartlett Publishes, Sudbury, MA, USA.

43. Etemadi-Aleagha A, Akhgari M, Abdollahi M. A brief review on oxidative stress and cardiac diseases. Mid. East. Pharmac. 2002; 10: 8-9.

44. Kohner EM, Stratton IM, Aldington SJ, Turner RC, Matthews DR. Microaneurysms in the development of diabetic retinopathy (UKPDS 42). UK Prospective Diabetes Study Group. Diabetologia 1999; 42:1107-1112.

45. Fetoui H, Garoui EM, Makniayadi F, Zeghal N. Oxidative stress induced by lamda-cyhalothrin (LTC) in rat erythrocytes and brain: attenuation by vitamin C. Environ. Toxicol. Pharmacol. 2008; 26: 225-231.

46. Fetoui H, Zribi N, Fakhfakh F, Keskes L. Quercetin Attenuates Lambda cyhalothrin induced Reproductive Toxicity in Male Rats. Environ. Toxicol. 2011; 28(12):673-680.

47. Yousef MI. Vitamin E modulates reproductive toxicity of pyrethroid lambda-cyhalothrin in male rabbits. Food Chem. Toxicol. 2010; 48: 1152-1159.

48. Ghosh R, Das T, Paramanik A, Maiti-Choudhury S. Lambda cyhalothrin elicited dose response toxicity on haematological, hepatic, gonadal and lipid metabolic biomarkers in rat and possible modulatory role of taurine. Toxicol. Forensic Med. Open. J. 2016; 1(2): 42-51.

49. Al-Amoudi, WM. Toxic effects of Lambdacyhalothrin, on the rat thyroid: Involvement of oxidative stress and ameliorative effect of ginger extract. Toxicol. Rep. 2018; 5: 728-736.

50. Fan JS, Liu DN, Huang G, Xu ZZ, Jia Y, Zhang HG. Panax notoginseng saponins attenuate atherosclerosis via reciprocal regulation of lipid metabolism and inflammation by inducing liver $\mathrm{x}$ receptor alpha expression. J. Ethnopharmacol. 2012; 142:732-738.

51. Qadir MI, Tahir M, Lone KP, Munir B, Sami W. Protective role of ginseng against gentamicin induced changes in kidney of albino mice. J. Ayub. Med. Coll. Abbottabad. (JAMC) 2011; 23(4): 53-57.

52. Martínez M, Ares I, Rodríguez J, Martínez M, Roura-Martínez D, Castellano V, Lopez-Torres B, Martínez-Larrañaga M, Anadón A. Pyrethroid insecticide lambda-cyhalothrin induces hepatic cytochrome P450 enzymes, oxidative stress and apoptosis in rats. Sci. Total Environ . 2018; (631-632):1371-1382.
53. Dhalla NS, Temsah RM, Netticadan T. Role of oxidative stress in cardiovascular diseases. J Hypertens. 2000; 18(6):655-673.

54. Bertram $\mathrm{C}$ and Hass R. Cellular responses to reactive oxygen species-induced DNA damage and aging. Biol. Chem. 2008; 389 (3):211-220.

55. Wang Y. Bulky DNA lesions induced by reactive oxygen species. Chem. Res. Toxicol. 2008; 21(2):276-281.

56. Michelangeli F, Robson MJ, East JM, Lee AG. The conformation of pyrethroids bound to lipid bilayers. Biochem. Biophys. Acta. 1990; 1028: 49-57.

57. Kelly SA, Harvilla KM, Brady TC, Abrano $\mathrm{KH}$, Leveir ED. Oxidative stress in toxicology: established mammalian and emerging piscine model systems. Environ. Health Perspective 1998; 106: 375-384.

58. Mossa AH, Heikal TM, Belaiba M, Raoelison EG, Ferhout H, Bouajila J. Antioxidant activity and hepatoprotective potential of Cedrelopsis grevei on cypermethrin induced oxidative stress and liver damage in male mice. BMC Complement. Alternat. Med. 2015; 15 (251): 1-10.

59. Aouey B, Derbali M, Chtourou Y, Bouchard M, Khabir A, Fetoui, H. Pyrethroid insecticide lambda-cyhalothrin and its metabolites induce liver injury through the activation of oxidative stress and pro-inflammatory gene expression in rats following acute and subchronic exposure. Environ. Sci. Pollut. Res. 2017; 24: 5841-5856.

60. Mossa $\mathrm{AH}$ and Nawwar GA. Free radical scavenging and antiacetylcholinesterase activities of Origanum majorana L. essential oil. Human Exp. Toxicol. 2011; 30: 1501-1513.

61. Mates J and Sánchez-Jiménez F. Antioxidant enzymes and their implications in pathophysiologic processes. Frontiers in bioscience: a journal and virtual library 1999; (4. D): 339-345.

62. Prakash M, Shetty MS, Tilak P, Anwar N. Total Thiols: Biomedical importance and their alteration in various disorders. Online J. Health Allied Scs. 2009; 8(2.2):1-9.

63. Jung CH, Seog HM, Choi IW, Choi HD, Cho HY. Effects of wild ginseng (Panax ginseng C.A. Meyer) leaves on lipid peroxidation levels and antioxidant enzyme activities in streptozotocin diabetic rats. J. Ethnopharmacol. 2005; 98:245-250.

64. Al-Harbi MS. Fipronil Induced Hepatotoxicity, Genotoxicity, Oxidative Stress and the Possible Ameliorative Effect of Ginseng. Br. J. Pharm. Res. 2016; 14(5): 1-14 
65. Diab AA, Abd El-Aziz EA, Hendawy AA, Hamza R Z. Possible Ameliorative Role of Propolis and Ginseng against Hepatotoxicity of Chlorpyrifos and Profenofos in Male Rats. J. Am. Sci. 2012; 8(8): 645-664.

66. Pietsch EC, Sykes SM, McMahon SB, Murphy ME. The p53 family and programmed cell death. Oncogene. 2008 Oct 27; 27(50): 6507-6521.

67. Otrocka-Domagała I. Sensitivity of skeletal muscle to pro-apoptotic factors. J. Veterinary Sciences 2011; 14(4): 683-694.

68. Gupta G, Chaitanya RK, Golla M, Karnati R. Allethrin toxicity on human corneal epithelial cells involves mitochondrial pathway mediated apoptosis. Toxicology in vitro 2013; 27: 2242-2248.

69. Wu A, Long L, Yugu L. DLM induces apoptotic cell death in cultured cerebral cortical neurons. Toxicol. App. Pharmacol. 2003; 187:50-57.

70. Wu A and Liu Y. Deltamethrin induces apoptosis and altered expression of P53, Bax, and Bcl2 in rat brain. Journal of Nature and Science $2015 ; 1: 1-2$.

71. Kumar A, Sasmal D, Bhaskar A, Mukhopadhyay K, Thakur A, Sharma N. DeltamethrinInduced Oxidative Stress and Mitochondrial Caspase-Dependent Signaling Pathways in Murine Splenocytes. Environmental toxicol. 2014; 31 (7): 808-819.

72. Sharma, D., Saxena, P., Singh, V., Sharma, R. 2010. Assessment of DNA degradation in lymphocytes of albino rat (Rattus norvegicus) under lambda cyhalothrin stress. World Appl. Sci. J. 11(1): 24-28.

73. Madkour NK. Protective effect of curcumin on oxidative stress and DNA fragmentation against lambda cyhalothrin-induced liver damage in rats. J. Appl. Pharm. Sci. 2012; 2 (12): 76-81.

74. Cheng W, Wu D, Zuo Q, Wang Z, Fan W. Ginsenoside Rb1 prevents interleukin-1 beta induced inflammation and apoptosis in human articular chondrocytes. Int. Orthop. 2013; 37: 2065-2070.

75. Kim HS, Lee EH, Ko SR, Choi KJ, Park JH, Im DS. Effects of ginsenosides Rg3 and Rh2 on the proliferation of prostate cancer cells. Arch. Pharm. Res. 2004; 27: 429-435.

76. Min JK, Kim JH, Cho YL, Maeng YS, Lee SJ, Pyun BJ. 20(S)-Ginsenoside Rg3 prevents endothelial cell apoptosis via inhibition of a mitochondrial caspase pathway. Biochem. Biophys. Res. Commun. 2006; 349: 987-994.
77. Nguyen CT, Luong TT, Kim GL, Pyo S, Rhee DK. Korean Red Ginsenginhibits apoptosis in neuroblastoma cells via estrogen receptor b-mediated phosphatidylinositol-3 kinase/Akt signaling. J. Ginseng Res. 2015; 39 (1): 69-75.

78. Choi JH, Jin SW, Park BH, Kim HG, Khanal T, Han HJ, Hwang YP, Choi-c JM, Chung YC, Hwang SK, Jeong TC, Jeong, HG. Cultivated ginseng inhibits 2, 4- dinitrochlorobenzene-induced atopic dermatitis-like skin lesions in NC/Nga mice and TNF- $\alpha$ /IFN-c-induced TARC activation in HaCaT cells. Food Chem. Toxicol. 2013; 56: 195-203.

79. Sheikh N, Javed S, Asmatullah, Ahmad KR, Abbas T, Iqbal J. Histological Changes in the Lung and Liver Tissues in Mice Exposed to Pyrethroid Inhalation. Walailak J Sci \& Tech. 2013; 11(10): 843-849.

80. McElroy MC and Kasper M. Review, The use of alveolar epithelial type I cell-selective markers to investigate lung injury and repair. Eur. Respir. J. 2004; 24: 664-673.

81. Geiser T. Mechanisms of alveolar epithelial repair in acute lung injury - a translational approach. Swiss Med. Wkly. 2003; 133: 586-590.

82. Bakewell WE, Viviano CJ, Dixon D, Smith GJ, Hook GE. Confocal laser scanning immunofluorescence microscopy of lamellar bodies and pulmonary surfactant protein A in isolated alveolar type II cells. Lab. Invest. 1991; 65: 87-95.

83. Soliman GM, ElShafey B, ElSerogy H. The effect of experimentally induced oxidative stress on rat lung and the possible protective role of pentoxifyllin: A histological and biochemical study. Egyptian J. Histol. 2009; 32: 33-45.

84. Boutten A, Venembre P, Seta N, Hamelin J, Aubier M, Durand G, Dehoux MS. Oncostatin M is a potent stimulator of alpha1-antitrypsin secretion in lung epithelial cells: modulation by transforming growth factor-beta and interferon gamma, Am. J. Respir. Cell. Mol. Biol. 1998; 18: 511-520.

85. Galaly SR, Abdul-Hamid M, Abdel-Latif M, Talaat RM. Rat airway changes after challenge with Trimellitic Anhydride: Effect of diethylcarbamazine citrate and omega-3 fatty acids. Egypt. J. Zool. 2014; 61: 251-274.

86. Davidson KG, Bersten AD, Barr HA, Dowling KD, Nicholas TE, Doyle I. Lung function, permeability, and surfactant composition in oleic acid-induced acute lung injury in rats. Am. J. Physiol. Lung Cell Mol. Physiol. 2000; 279: L1091-L1102. 
87. Andriana BB, Tay TW, Maki I, Awal MA, Kanai Y, Kurohmaru M, Hayashi Y. An ultrastructural study on cytotoxic effects of mono (2ethylhexyl) phthalate (MEHP) on testes in Shiba goat in vitro. J. Vet. Sci. 2004; 5: 235-240.

88. Moushumi-Priya A. and Jayachandran S. Induction of apoptosis and cell cycle arrest by Bis (2-ethylhexyl) phthalate produced by marine Bacillus pumilus MB 40. Chem. Biol. Interact. 2012; 195: 133-143.

89. Yao PL, Lin YC, Richburg JH. TNF alpha-mediated disruption of spermatogenesis in response to
Sertoli cell injury in rodents is partially regulated by MMP2. Biol. Reprod. 2009; 80: 581-589.

90. Razani B, Schlegel A, Liu J, Lisanti MP. Caveolin-1, a putative tumour suppressor gene. Biochem. Soc. Trans. 2001; 29: 494-499.

91. Park DS, Cohen AW, Frank PG. Caveolin-1 null (-/-) mice show dramatic reductions in life span. Biochemistry 2003; 42: 15124-15131.

92. Grewal KK, Sandhu GS, Kaur R, Brar RS, Sandhu HS. Toxic impacts of cypermethrin on behavior and histology of certain tissues of albino rats. Toxicol. Int. 2010; 17: 94-98. 
الملخص العربى

\section{التأثير الوقائي للجنسنج على السميه الناتجه من لامبادا سيهالوثرين على رئه الجرذان الإبضاء}

كريم زايد، هناء محمود محمد، ثناء محمود عبد التواب، منال عبد الحميد

\section{قسم علم الحيوان، كليه العلوم، جامعه بنى سويف، مصر}

المقدمه: يعتبر لامبادا سيهالوثيرين مبيد حشري من النوع الثانى من المبيدات الحشريه البيريثرويديه لله تطبيقات عديده في الزر اعه والصحه العامه وصحه الحيو ان. على الرغم من الادعاءات أن تاثثيره السمى على الثديات منخفض فقد أثثتث العديد من الدر اسات أن له تاثثر سمى على الثذييات عن طريق تحفيز جهد الاكسده مما يسبب تلفًا حادًا في الرئة ومن ثم يشكل خطر ا على صحه الانسان و الحيو ان. الهُف: تهدف هذه الدر اسه الي التحقق من الدور الوقائى و المحسن لجر عتين من مستخلص نبات البانكس جينسنج

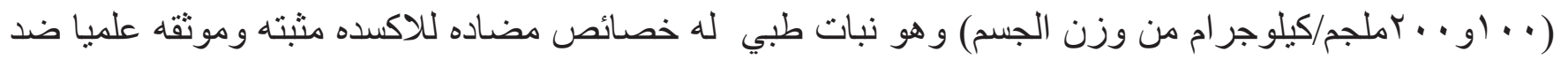

الآثار السمية الناتجة عن التعرض لمبيد لامبادا سيهالوثيرين في رئه الجرذان البيضاء لمده ـ ج يوماً.

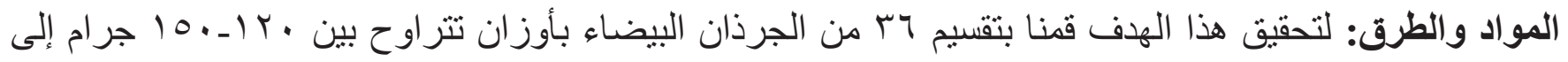
آمجموعات بو اقع 7 فى كل مجموعة. المجموعة الاولى ( المجموعة الضابطة): و التى أعطبت محلول ملحى عن

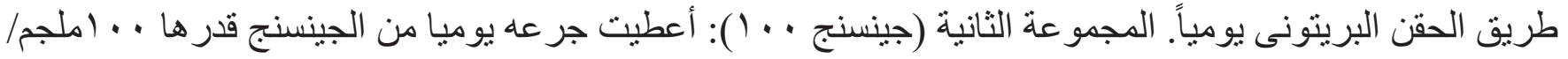
كيلوجر ام من وزن الجسم (مذابة فى محلول ملحى) عن طريق الحقن البريتونى. المجموعة الثالثة (جينسنج . . Y): أعطيت جر عة يو ميا من الجينسنج قدر ها .اكلجم/كيلوجر ام من وزن الجسم (مذابه فى محلول ملحى) عن طريق الحقن البريتونى ـ المجموعة الرابعة (لامبادا سيهالوثيرين): باستخدام انبوبة فموية تم تجريعها عن طريق الفم بمبيد

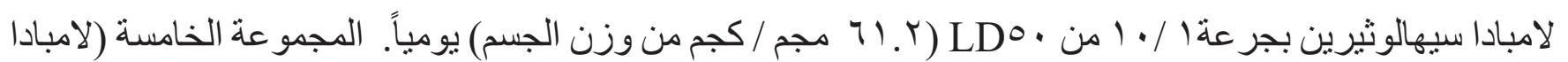
سيهالوثيرين+ + . ( ): اعطيت يو مياً نفس جر عه المجمو عه الر ابعه من لامبادا سيهالثيرين تليها على الفور نفس جر عة المجمو عة الثانية من الجينسنج. المجمو عة السادسة (لامبادا سيهالوثيرين+ . . ץ): اعطيت يو مياً نفس جر عة المجموعة الر ابعة من لامبادا سيهالثيرين تليها على الفور نفس جر عة المجمو عة الثالثة من الجينسنج. تم تعديل الجرعات اسبو عيا وفقا للتغير ات فى وزن الجسم حتى نهاية فترة التجربة. النتائج: بعد انتهاء فتره التجريبية ( بعد · آ يومًا) تم تسجيل الأوزان النهائية للجرذان، وتم حساب نسبه زيادة وزن الجسم. تم ذبح جميع مجموعات الجرذان تحت التخدير من ثنائي إيثيل الأثير. تم استخر اج الرئة ، و غسلها بمحلول

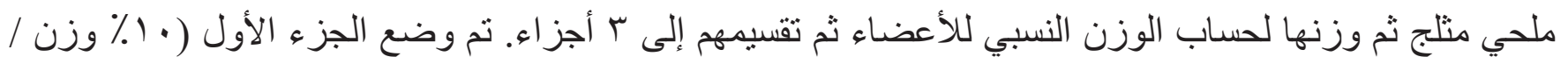
حجم) في محلول ملحي معادل بالفوسفات ، لمدة • ( دقائق باستخدام جهاز طرد مركزي عند .... دورة في الدقيقة 
تم الحصول على محلول متجانس و اضح وتجميده عند ـ • 1 درجة مئوية للتحليل اللاحق لمعلمات الإجهاد التأكسدي ، تم تجميد الجزء الثاني عند ـ • د درجة مئوية لتحليل التعبير الجيني و البروتينى. تم استخدام الجزء الثالث للفحص بو اسطه المجهر الضوئى والالكترونى.

قد تسبب التسم ب لامبادا سيهالوثيرين فى انخفاض فى الاوزان النهائيه للجرذان و الاوزان النسبية للرئه. وقد اظهرت نتائج تحاليل دلالات جهد التأكسد فى انسجه الرئة ان التسمم بلامبادا سيهالوثيرين قد تسبب فى زياده ملحوظه في مستوى (MDA) و انخفاض ملحوظ في نشاط الانزيمات المضاده للاكسده (CAT وSOD ( ومستوى الثيول الكلى (T. thiol) .بالاضافه الى ذللك زياده ملحوظه في مستوي mRNA و التعبير البروتيني لجين سor ( المنشط لموت الخلايا المبرمج) مصحوبا بنقص في و مستوي mRNA و التعبير البروتيني لجين Bc1- Y ( المثبط لموت الخلايا

$$
\text { المبرمج) فى الرئة. }
$$

بالاضافة الى ذلك اظهر الفحص بالمجهر الضوئي لعينات الرئة للجرذان المسممه بلامبادا سيهالوثيرين ان اعطاء لامبادا سيهالوثيرين يسبب تغير ات تنكسية متعدده فى الأنسجة الرئوية بالمقارنة بالمجمو عة الضابطة. هذه التغير ات تتمثل فى تلف فى الحويصلات الهو ائية فى شكل ضيق فى الحويصلات الهو ائية مع تعويض تمدد الحويصلات المجاوره مصحوبا بزياده فى سمك الحواجز بين الحويصلات و التهاب القصيبات الهوائية يظهر في شكل تمدد في القصيبات الهو ائية وزياده في سملك جدار ها وتسرُب لكرات الدم الحمر اء داخل تجويفه. احتقان في الاوعيه الدمويه وزيادة في سمك جدار ها وارتشاح خلوى فى النسيج المجاور لها بالاضافة الى نزيف في بعض الانسجة.

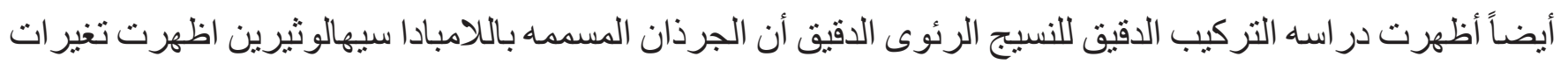
على مستوى التركيب الدقيق تتضمن فجوات سيتوبلازميه وبكنزة في الانوية واختفاء للزُّ غَيْبَات الدقيقه فى النوع الثنانى من الخلايا الرئوية اما النوع الاول من الخلايا الرئويه فأظهر انكماش فى النواة وفجوات سيتوبلازمية بالاضافة الى زيادة سمك الحاجز بين الحويصلات. أظهرت الدراسة أيضا ان معاملة الجرذان المعرضة للامبادا سيهالوثيرين بالجنسنج قد أحدث ثأثثرات محسنة في و الرئة. هذا التحسن نتيجة تأثيره المضاد للاكسدة و القدرة الفائقة على التخلص من الثوارد الحرة من أنسجة الرئة. كلتا الجرعتين المختبرتين من الجنسنج ادت الى انخفاض بشكل ملحوظ فى مستوى ومستوى التعبير البروتيني

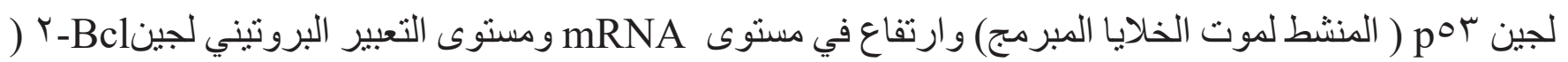
المثبط لموت الخلايا المبرمج) وكثفت عن تحسن كبير واستعادة الأنسجة الطبيعية و التركيب الدقيق للرئة ولكن جر عه ( · · م ملجم/كيلوجر ام من وزن الجسم) من الجنسنج أظهرت نتائج افضل. الخلاصه: ونستخلص من هذه الدر اسه ان المعالجه بالجينسنج له تأثثر وقائي ضد جهد الأكسده الناتج من التعرض لمبيد لامبادا سيهالوثيرين وما يصاحبه من موت الخلايا المبرمج و التغير ات الهيتوباثولوجية و التركيبية الدقيقة في رئه

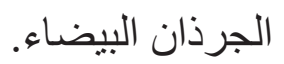

